\title{
Neural Tube Defects, Folic Acid and Methylation
}

\section{Apolline Imbard ${ }^{1,2}$, , Jean-François Benoist ${ }^{1}$ and Henk J. Blom ${ }^{2}$}

1 Biochemistry-Hormonology Laboratory, Robert Debré Hospital, APHP, 48 bd Serrurier, Paris 75019, France; E-Mail: jean-francois.benoist@rdb.aphp.fr

2 Metabolic Unit, Department of Clinical Chemistry, VU Free University Medical Center, De Boelelaan 1117, Amsterdam 1081 HV, The Netherlands; E-Mail: h.blom@vumc.nl

* Author to whom correspondence should be addressed; E-Mail: apolline.imbard@rdb.aphp.fr; Tel.: +33-1-4003-4722; Fax: +33-1-4003-4790.

Received: 27 July 2013; in revised form: 30 August 2013 / Accepted: 3 September 2013 / Published: 17 September 2013

\begin{abstract}
Neural tube defects (NTDs) are common complex congenital malformations resulting from failure of the neural tube closure during embryogenesis. It is established that folic acid supplementation decreases the prevalence of NTDs, which has led to national public health policies regarding folic acid. To date, animal studies have not provided sufficient information to establish the metabolic and/or genomic mechanism(s) underlying human folic acid responsiveness in NTDs. However, several lines of evidence suggest that not only folates but also choline, B12 and methylation metabolisms are involved in NTDs. Decreased B12 vitamin and increased total choline or homocysteine in maternal blood have been shown to be associated with increased NTDs risk. Several polymorphisms of genes involved in these pathways have also been implicated in risk of development of NTDs. This raises the question whether supplementation with B12 vitamin, betaine or other methylation donors in addition to folic acid periconceptional supplementation will further reduce NTD risk. The objective of this article is to review the role of methylation metabolism in the onset of neural tube defects.
\end{abstract}

Keywords: neural tube defects; folate; methylation; choline; methionine; homocysteine; MTHFR; B12 vitamin 


\section{Introduction}

Neural tube defects (NTDs) are common complex congenital malformations of the central nervous system resulting from failure of the neural tube closure during embryogenesis. The prevalence of NTDs varies widely between 1 and 10 per 1,000 births, depending on geographic region and ethnical grouping, making them one of the most frequent congenital malformations [1].

NTDs can be classified in "open" NTDs in which the neural tissue is exposed and "closed" NTDs with the neural tissue covered by tissue [2,3]. "Open" NTDs include craniorachischisis resulting from a total failure of neurulation with most of the brain and the entire spinal cord remaining open, anencephaly when the defect occurs in the cranial region and spina bifida cystica when the defect is localized in the lumbosacral area. In this last defect, if only meninges and cerebrospinal fluid herniates through the defect, it is referred as meningocele, while a myelomeningocele directly involves spinal cord and/or nerve roots. "Closed" NTDs, encompass encephalocele and spina bifida occulta. Encephalocele is a defect of the bony skull through which part of the brain herniates. Spina bifida occulta, results from a gap in one or more vertebral arches in the lumbosacral area, but the spinal cord and meninges remain entirely within the vertebral canal. In these types of defects the folds may have come together, but the normal fusion process was disrupted.

Unlike the cranial defects, which are usually lethal at or before birth, spina bifida is compatible with postnatal survival. Spina bifida cystica is more severe; these patients being at increased risk for morbidity and mortality throughout their life. Only $1 \%$ of children born with an open NTD are free from disability. Affected patients usually have anesthesia of the skin, abnormalities of the hips, knees, and feet, reduced ability to walk or need a wheelchair, have little or no bowel and/or bladder control, and require frequent surgical interventions to minimize the effects of hydrocephalus [4]. Thus, the lifetime medical costs of spina bifida affected patients are considerable [5,6]. Finally, spina bifida occulta is the mildest form of spina bifida and is compatible with normal life.

NTDs have complex and multifactorial etiologies in which both genetic, life style and environmental factors appear to be involved. Chromosomal anomalies can be associated with NTDs, but represent only $2 \%$ to $16 \%$ of isolated NTDs [7]. Several observations support the view that genetic factors are involved in NTDs formation: first, an increased risk in some ethnic groups (e.g., Irish and Mexican) and second, the high recurrence risk for siblings of affected individuals $[1,8,9]$. In addition to genetic factors, environmental influences such as parental occupation, maternal obesity, and maternal nutritional status have been related to NTDs [1,2,8]. Particularly, it has been suggested more than 40 years ago that maternal folate status is associated with NTD risk [10]. A substantial number of reviews have been published on NTDs and folic acid [11-16]. Over the years, more and more studies suggest that not only folate but whole methylation metabolism could be involved in the etiology of NTDs. This review will focus on the involvement of methylation metabolism in the onset of neural tube defects.

\section{Neurulation and Neural Tube Defects}

Neurulation is a fundamental event in embryogenesis that culminates in the formation of the neural tube, which is the precursor of the brain and spinal cord (reviewed in [17-19]). Neurulation begins 
with the formation of the neural plate as a thickening of the dorsal ectoderm. Neural plate then shapes, with the processes including convergent extension. Then the neural plate bends, elevates and begins to move towards the midline. The extremities come into contact and fuse to create the neural tube, which, thereafter, becomes covered by epidermal ectoderm. Closure of the cranial neural tube is essential not only for maintenance of brain development but also for initial formation of much of the skull [20]. The fusion of neural folds, is subject to debate concerning the number of initiation sites of fusion and their location [21]. Neural tube closure depends upon the cooperation of several mechanisms: convergent extension of the neural plate, neuroepithelial apoptosis, neural crest cell migration, proliferation and differentiation. The development and closure of the neural tube is completed 28 days after conception. If neural tube closure fails, the embryo develops an NTD. However, some authors also support the possibility of some NTD resulting from a closed neural tube secondarily reopening [21].

\section{NTD Prevention via Folate}

\subsection{The Folate Story}

Since the 18th century, a relationship between social classes and prevalence of NTDs has been noted [22]. Lower social classes tend to have decreased concentrations of various vitamins, including folate, as a consequence of poor diet [23]. In the 60s it was suggested that low folate status was one specific risk factor for NTD by the Hibbard and Emery groups [10,24,25]. In a series of non-randomized cases/controls trials Smithells and coworkers showed that periconceptional supplementation with multivitamin containing $0.36 \mathrm{mg}$ of folic acid (FA) reduced the recurrence rate of NTDs from $5.9 \%$ to $0.5 \%$ [26-29]. Although strongly suggestive, these reports were not regarded as definitive proof because the assignment to treatment groups was not randomized and because FA was given as a part of a multivitamin supplement.

In parallel, biological arguments have suggested that insufficient folate intake was related to NTDs. Although several studies failed to reach significance [30-36], most have found lower plasma folates [37-40], red blood cells (RBC) folates [37-39,41] or amniotic fluid (AF) folates [42] in women carrying NTD affected fetuses, or who gave birth to NTD affected offsprings, compared to control pregnant women. Interestingly, folates concentrations, even if decreased, remained generally within reference ranges.

A substantial number of cases/controls studies followed those from Smithells and coworkers (reviewed in [43]) and explored the relation between administration of folates and NTDs (recurrence) risk. One performed in Cuba with $5 \mathrm{mg}$ /day of FA alone showed a recurrence rate dropping from 3.5\% to $0 \%$ [44]. Others [45-51] have shown evidence of decreased NTD occurrence ranging between $35 \%$ to $75 \%$, associated with FA containing multivitamin and high food folate consumption. In contrast, few studies did not detect a significant effect from dietary folate or multivitamin supplements on NTDs occurrence [52,53].

In parallel, Laurence et al. reported in 1981 the first double-blind randomized controlled trial for the use of FA in the periconceptional period and assessed for the first time that $2 \mathrm{mg} /$ day of FA could prevent recurrence of NTDs [54]. However, the methodology used was criticized due to the small number of women included and the a posteriori change of two women with NTDs affected fetuses 
from the FA group to the non-compliers group [55]. In 1991, the Medical Research Council of the United Kingdom (MRC-UK) published the results from a large multicenter double-blind randomized trial [56]. This study is to date the largest and most important randomized trial comparing the effect of $4 \mathrm{mg}$ /day FA versus multivitamin supplement (with or without FA) and versus placebo in a large cohort of women that had antecedents of NTD-affected children. The FA supplemented group (with or without multivitamins) had a decrease of $72 \%$ in the number of NTDs compared to placebo, while the multivitamin supplement without folic acid did not showed any significant protective effect. These results were decisive in demonstrating the specific preventive effect of FA on the recurrence risk of NTDs. The MRC trial was shortly followed by the largest occurrence risk study performed by Czeizel and Dudas, referred as the "Budapest trial" [57]. This randomized, large-scale trial compared the NTDs prevalence in women receiving $0.8 \mathrm{mg} / \mathrm{d}$ of FA versus trace element supplements. The results demonstrate a complete prevention of NTDs with no occurrence in the FA group among 2,104 women compared to six NTDs cases among 2,052 women in the control group. More recently, a large interventional study performed in China [58] demonstrated a lower occurrence rate with the use of $0.4 \mathrm{mg}$ FA in the periconceptional period. This study also points out a greater reduction in NTD risk in areas with high baseline rates.

The MRC and Budapest trials, together with the China interventional study, undoubtedly showed a reduction in the occurrence and recurrence of NTDs with periconceptional FA supplementation, which has influenced public health policy, but the non-homogeneity of the doses of FA used in these trials makes it difficult to assess the dose of FA supplement that should be recommended in the prevention of NTDs.

\subsection{National Programs for NTDs Prevention}

There are three potential approaches for the delivery of folic acid to the general population: improvement of dietary habits, fortification of food and use of supplements [59]. In 1992 the CDC recommended the use of periconceptional FA supplementation of $4 \mathrm{mg}$ per day for high risk women and $0.4 \mathrm{mg} /$ day for all others [59]. Following these recommendations, Stevenson et al. observed a decline in NTD prevalence in USA [60]. In 1996, the Food and Drug Administration authorized food fortification with FA in the USA and this became mandatory in 1998 [61]. Grains and cereals were enriched with FA at a concentration of $1.4 \mathrm{mg} / \mathrm{kg}$ in order to increase the average consumption of women of reproductive age by around $0.1 \mathrm{mg}$ per day. Many other countries including all North America countries, Australia and the majority of South America countries established similar policies (Figure 1).

Food fortification significantly increased serum and RBC folates among childbearing-aged women and decreased the prevalence of low folate concentrations [62-66]. A "positive side effect" was also observed with fortification: the decrease of plasma total homocysteine concentrations in the population, a cardiovascular risk factor [67,68]. Numerous studies have evaluated the prevalence of NTDs before and after food fortification, and the results are summarized in Table 1. Most of them show a decrease between $10 \%$ and $80 \%$ in the total NTD prevalence associated with the introduction of food FA fortification. Moreover, the decline in NTD was most obvious in areas [69] or ethnic groups with high baseline prevalence [70]. 
Figure 1. Countries with mandatory folic acid food fortification, adapted from [71].

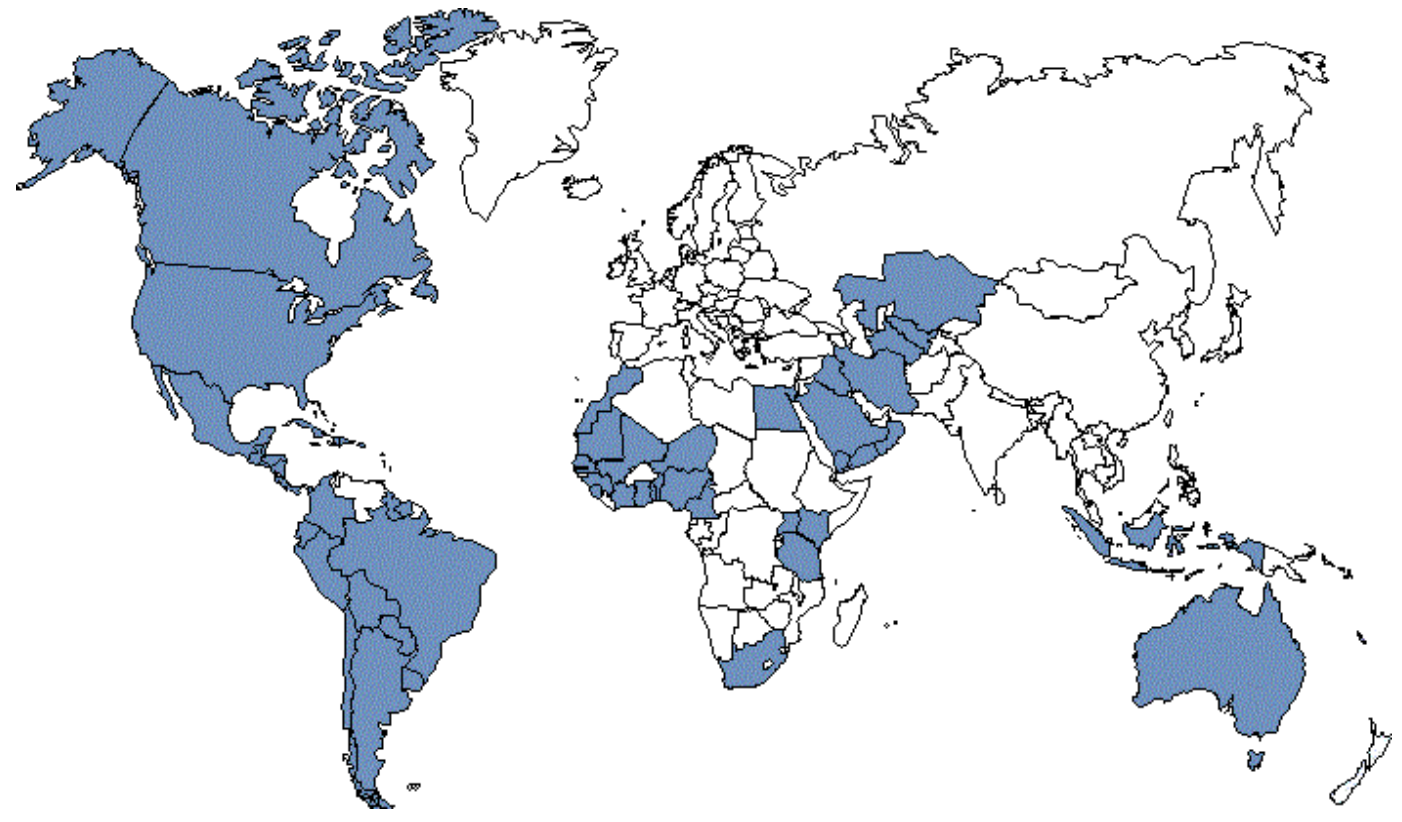

Table 1. Reduction in NTD rates with folic acid fortification.

\begin{tabular}{|c|c|c|c|c|c|c|}
\hline \multirow{2}{*}{ Reference } & \multirow{2}{*}{ Area/State } & \multicolumn{2}{|c|}{ Period studied } & \multicolumn{2}{|c|}{$\begin{array}{l}\text { Total NTD prevalence } \\
\text { rate (/1,000 births) }\end{array}$} & \multirow{2}{*}{$\begin{array}{l}\% \\
\text { Reduction }\end{array}$} \\
\hline & & $\begin{array}{l}\text { Before } \\
\text { fortification }\end{array}$ & $\begin{array}{l}\text { After } \\
\text { fortification }\end{array}$ & $\begin{array}{l}\text { Before } \\
\text { fortification }\end{array}$ & $\begin{array}{l}\text { After } \\
\text { fortification }\end{array}$ & \\
\hline Ray et al. [72] & Ontario & 1994-1997 & $1998-2000$ & 1.13 & 0.58 & 49 \\
\hline Honein et al. [73] & USA & 1995-1996 & 1998-1999 & 0.38 & 0.31 & 19 \\
\hline Persad et al. [74] & Nova Scotia & 1991-1997 & $1998-2000$ & 2.58 & 1.17 & 55 \\
\hline Williams et al. [75] & USA & 1995-1996 & 1998-1999 & 0.76 & 0.56 & 26 \\
\hline De Wals et al. [76] & Quebec & 1992-1997 & $1998-2000$ & 1.89 & 1.28 & 32 \\
\hline Palomaki et al. [77] & Maine & 1993-1996 & $1998-2000$ & 1.23 & 1.07 & 13 \\
\hline $\begin{array}{l}\text { Lambert-Messerlian } \\
\text { et al. [78] }\end{array}$ & Rhode Island & 1991-1996 & $1998-2000$ & 3.8 & 3.3 & 13 \\
\hline Simmons et al. [79] & Arkansas & 1993-1995 & $1999-2000$ & 1.09 & 0.82 & 25 \\
\hline Liu et al. [64] & Newfoudland & 1991-1997 & 1998-2001 & 4.36 & 0.96 & 78 \\
\hline Chen et al. [80] & Costa Rica & 1996-1998 & 1999-2000 & 9.7 & 6.3 & 35 \\
\hline Hertrampf et al. [81] & Chile & $1999-2000$ & $2001-2002$ & 1.70 & 1.01 & 41 \\
\hline $\begin{array}{l}\text { Lopez-Camelo } \\
\text { et al. [82] }\end{array}$ & Chile & $1982-1991$ & 2001-2002 & 1.57 & 0.80 & 49 \\
\hline Canfield et al. [83] & USA & 1995-1996 & $1999-2000$ & 0.71 & 0.5 & 30 \\
\hline De Wals et al. [69] & Canada & 1993-1997 & $2000-2002$ & 1.58 & 0.86 & 46 \\
\hline Chen et al. [84] & California & 1989-1996 & $1998-2003$ & 0.59 & 0.70 & No decline \\
\hline Sayed et al. [85] & South Africa & $2003-2004$ & 2004-2005 & 1.41 & 0.98 & 31 \\
\hline Amarin et al. [86] & Jordan & $2000-2001$ & 2005-2006 & 1.85 & 1.07 & 49 \\
\hline
\end{tabular}

Only one study [84] did not observe any effect of fortification although this study highlights a continuous decreasing prevalence of NTD before FA food fortification. This emphasizes the difficulty in interpreting these results because numerous other factors such as life-style changes, ethnic 
background drift or socio-economic conditions can influence NTDs risk. Other confounding factors, such as increased prenatal diagnosis and concomitant termination of NTD affected pregnancies will also have influenced the results. Nevertheless, the sum of all these studies provides evidence that folic acid fortification decreased the incidence of NTDs. Finally, economic analyses have shown that food fortification was a success in terms of costs/benefit ratio $[6,87,88]$.

Despite its efficacy, two issues are still a matter of debate regarding food fortification: the appropriate dose to use and potential side effects [89]. Several authors argued that the current amount of FA might be too low to prevent all folic-acid "sensitive" NTDs and favor to increase the FA dose [90-93]. Their logic is supported by the fact that there seems to be a dose response effect in NTD prevention related to folate supplementation. In fact, NTD rates seem to inversely correlated with the amount of folate intake and/or with maternal RBC and serum folate concentrations [66,94-96]. On the other hand, probably not all NTDs cases are sensitive to FA. Reduction of NTDs prevalence after FA food fortification seems to be correlated with NTD baseline prevalence (Figure 2). It remains a challenge to establish whether the number of FA preventable and FA non-preventable NTD cases [97,98]. When Figure 2 is extrapolated it can be deduced that folic acid food fortification will not reduce the number of NTDs below about 0.5 per 1,000 births.

Figure 2. Reduction rate of NTDs after FA food fortification depending on baseline prevalence.

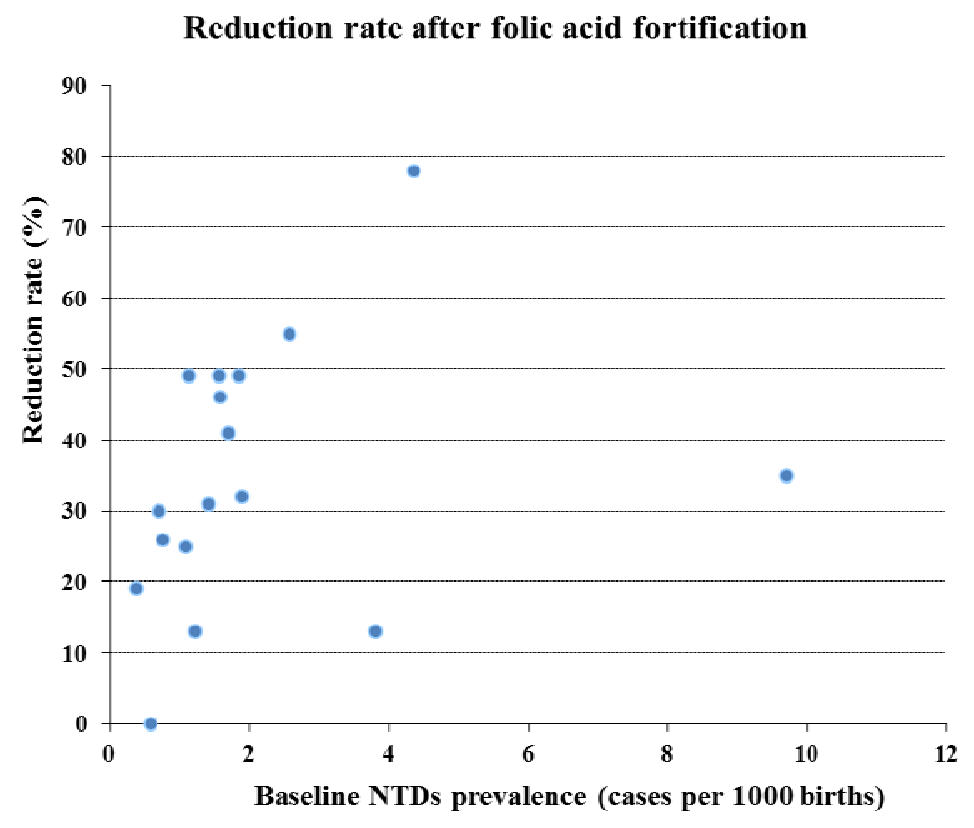

Possible side effects of high dose of FA are still being debated (reviewed in [99]). Historically, concerns surrounding FA use have focused on the possibility that folic acid could mask pernicious anemia caused by B12 deficiency [100]. However, it is now recognized that the diagnosis of pernicious anemia should be based on serum B12 measurements, which are not influenced by folates, and not only on haemoglobin concentration or haematocrit. Recently, focus has shifted to the possibility that FA intake might lead to epigenetic changes and concerns about cancer development and outgrowth $[89,101]$. However, a very recent meta-analysis of the effects of B vitamins has not shown that there is an increased risk of cancer incidence [102]. Moreover, since the implementation of 
mandatory folic acid fortification in the United States in 1998 both incidence and mortality of colorectal cancer have continued to decline [103]. These observations, led the European Food safety authority to report that the current evidence does not show an association between high folic acid intakes and cancer risk but they were also unable to confidently exclude such a risk [89]. Finally, some animal studies using FA supplementation reported unexpected side effects of FA on embryonic development [104,105]. Pickell et al. observed embryonic delay and growth retardation using high doses of FA in pregnant mice. In their study, Marean et al. used short- or long-term FA enriched diet at doses comparable with those used in food fortification and observed increased NTD rates in some mouse models of non-FA responsive NTDs.

In the non-fortified countries, including the whole of Europe, health policies vary from no recommendations to dietary recommendations with or without supplements either for selected at-risk women or all women of childbearing age $[106,107]$. Despite these actions, clear decreases in NTDs rates have not been seen in all these countries [106-109]. The awareness of the benefits of folic acid supplementation improved with health campaigns [110] but many women, especially in their first pregnancy, are still unaware that folic acid must be taken before conception [107,111-113]. Ray et al. reviewed the prevalence of folic acid supplementation in community programs worldwide and found that associations with low uptake were unintentional pregnancies, young age and low income mothers [114]. As such, some authors are arguing for food fortification while others argue for more health education campaigns [115-118].

\section{Folate and Methylation Metabolism}

Folate is an essential water soluble B-vitamin provided in the diet, particularly from fruits and vegetables. In general, the term folic acid is applied to the more stable synthetic form while the term folate referred to the natural forms. Natural dietary folates consist mainly of 5-methyltetrahydrofolate (5-MeTHF) and 10-formyltetrahydrofolate (10-formylTHF) in their polyglutamated forms. These consist of one to six glutamate molecules joined in a peptide linkage. In the gut polyglutamates are required to be hydrolyzed into monoglutamates to be absorbed $[119,120]$. Folic acid has only one glutamic residue and first needs to be reduced to the naturally bioactive form tetrahydrofolate (THF), through two reduction reactions catalyzed by dihydrofolate reductase. The addition of a one-carbon unit and subsequent reduction steps produce 5-MeTHF-monoglutamate, which is the main circulating form in blood [12]. 5-MeTHF is taken up in to the cells by tissues specific folate receptors or carriers proteins, where they are accumulated after their transformation into polyglutamates. Polyglutamated folates do not cross membranes and are in this way retained in the cell. They also have a higher affinity for enzymes involved in folate metabolism than their monoglutamates counterparts.

In cell (Figure 2), 5-methylTHF can donate a methyl-group for homocysteine remethylation to methionine by methionine synthase. The resulting THF can directly be converted into 5,10-methylene THF by the action of serine hydroxymethyltransferase, which has a cytosolic as well as a mitochondrial isoform. THF can also be converted in 5,10-methyleneTHF (5,10-MTHF), via 10-formylTHF and 5,10-methenylTHF catalyzed by the trifunctional enzyme methylene-tetrahydrofolate dehydrogenase (MTHFD1) that has formyltetrahydrofolate synthetase, methenyl-tetrahydrofolate cyclohydrolase and methylenetetrahydrofolate dehydrogenase activity. Tetrahydrofolate synthetase activity is also present 
in the mitochondrion, in the form of the monofunctional MTHFD1L enzyme. 5,10-MTHF can be reduced to 5-MeTHF by the riboflavin (vitamin B2) dependent enzyme methylenetetrahydrofolate reductase (MTHFR).

Mitochondria contain around $40 \%$ of total cellular folates, and particularly, folates resulting from the catabolism of dimethylglycine, sarcosine and glycine. Polyglutamated folates in mitochondria and cytoplasm constituted two distinct pools that are not directly in equilibrium through folates exchange. The exchange of formate, a 1-C unit equivalent between the two compartments contributes indirectly to this equilibrium $[121,122]$.

In cytoplasm, folates are involved in three principal metabolic pathways that comprise: homocysteine remethylation, de novo purine biosynthesis and de novo dTMP biosynthesis. De novo synthesis of dTMP from deoxyuridylate involves the enzyme thymidylate synthase which is in competition with MTHFR for the cytoplasmic 5,10-MTHF. De novo purine nucleotide biosynthesis is a 10 -step pathway that uses 10 -formylTHF to supply the number 2 and 5,10-methenyl-THF to supply the number 8 carbons of the purine ring.

In the remethylation pathway folates closely relate to betaine, choline and cobalamin metabolisms [123-125] (Figure 3). Likely, in all tissues except red blood cells, homocysteine can be remethylated by using 5-MeTHF as methyldonor for the ubiquitous methionine synthase which requires cobalamin as a cofactor. The essential amino acid methionine can subsequently be converted in S-adenosyl-methionine, also called the universal methyl donor. S-adenosyl-methionine is the substrate for almost all methylation reactions in mammals such as methylation of proteins, nucleic acids, lipids, neurotransmitters and creatine synthesis [126]. Upon transfer of the methyl group, S-adenosyl-methionine is converted to S-adenosyl-homocysteine, which is hydrolyzed by $\mathrm{SAH}$ hydrolase (SAHH) to adenosine and homocysteine. If inadequate amounts of 5-MeTHF or cobalamin are available, homocysteine accumulates. Because the equilibrium of the SAHH reaction favours S-adenosyl-homocysteine formation, an accumulation of homocysteine can lead to the buildup of S-adenosylhomocysteine, a potent inhibitor of numerous methyltransferases. In specific tissues (kidney and liver), homocysteine can also be remethylated by betaine-homocysteine methyl-transferase (BHMT) using betaine. Betaine is provided in the diet and, probably in higher quantities from choline catabolism. Choline itself can be provided either in the diet or by two biosynthesis pathways which act through the methylation of phosphatidylethanolamine or through the CDP-choline pathway. Finally, homocysteine can be eliminated via the transulfuration pathway into cysteine.

\section{Putative Mechanisms of Folates Action}

Folates play a key role in NTD susceptibility however it is noteworthy that maternal levels in most affected pregnancies are still within the "normal" range. Animals fed with inadequate folic acid amounts leading to significant reduction in maternal circulating folates and increased homocysteine levels do not result in NTDs nor an apparent effect on embryonic folates content $[127,128]$. On the other hand, embryos from these mothers showed intrauterine growth retardation [128]. As such, it is likely that profound maternal folate deficiency is not sufficient to cause NTDs. 
Figure 3. Simplified folate metabolism and its interrelation with the remethylation cycle, vitamin B12 and choline metabolism. Enzymes are in blue. Blue arrows indicate metabolites that can be provided by the diet. BADH, betaine aldehyde dehydrogenase; BHMT, betaine-homocysteine methyltransferase; CBS, cystathionine $\beta$-synthase; $\mathrm{CHDH}$, choline dehydrogenase; DDH, dimethylglycine dehydrogenase; MAT, methionine adenosyltransferase; MT, methyltransferases; MTHFR, methylenetetrahydrofolate reductase; MTHFD, methylenetetrahydrofolate dehydrogenase/methylenetetrahydrofolate cyclohydrolase/formyltetrahydrofolate synthetase; 5-MeTHF, 5-methyltetrahydrofolate; 5,10-MTHF, 5,10-methylenetetrahydrofolate; MTR, methionine synthase; MTRR, methionine synthase reductase; SAHH, S-adenosylhomocysteine hydrolase; SARDH, sarcosine dehydrogenase; SHMT, serine hydroxymethyltransferase; THF, tetrahydrofolate.

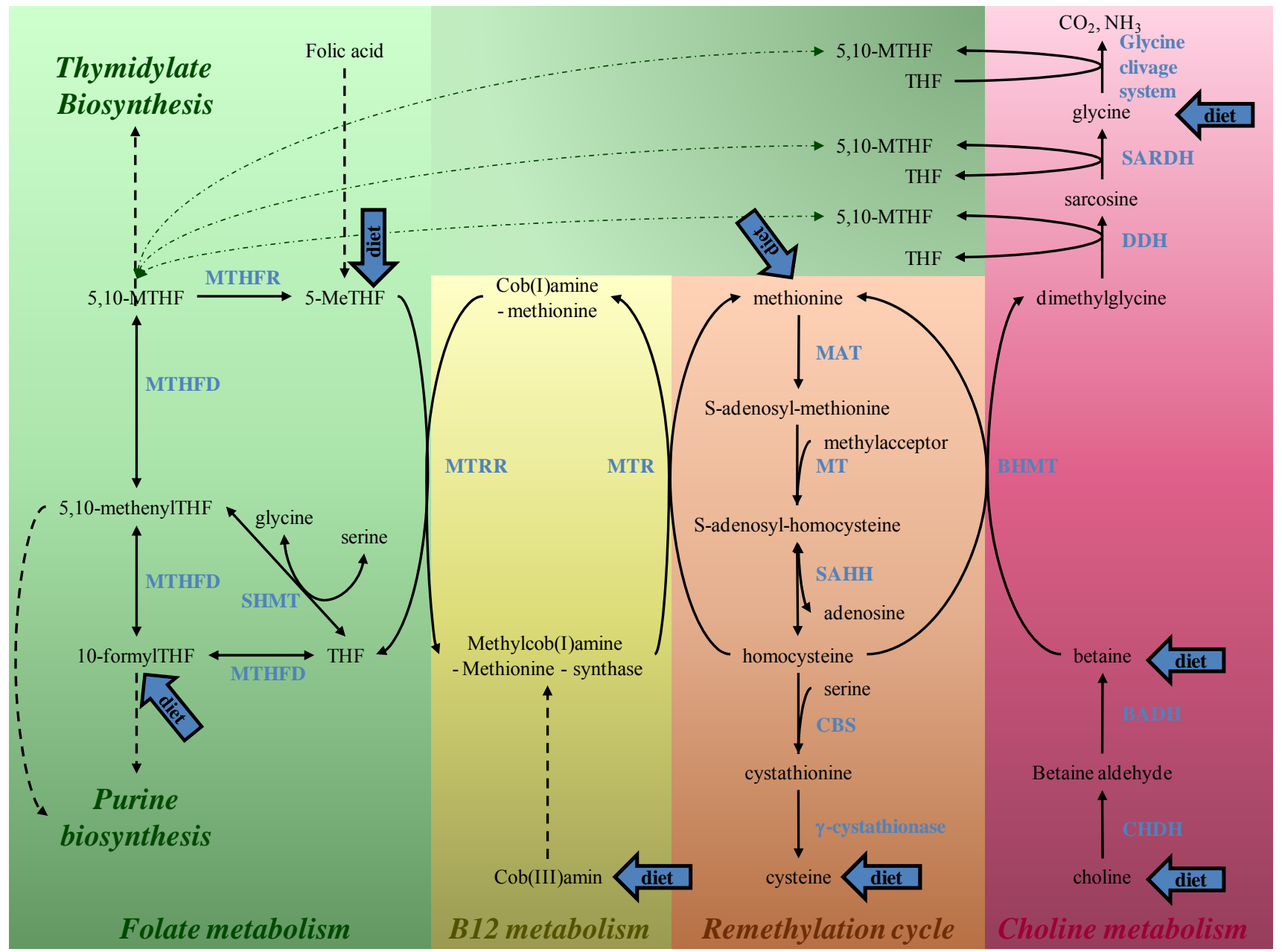

It has been suggested that specific folates deficiency at the cellular level may be responsible for NTDs due to disturbed folates bioavailability. In fact, autoantibodies binding folate receptors and blocking the cellular uptake of folates have been described more frequently in women with NTDs affected fetuses [129]. In mice, inactivation of the gene FOLR1 coding for a protein involved in folate transport in neuroepithelial, neural crest and visceral endoderm cells results in neural tube, heart and cranial structure malformations [130-132]. Supplementing heterozygous FOLR1 knock-out mice with FA rescued the embryos in a dose-dependent manner [133]. Conversely, inactivation of the more expressed folate transporter FOLR2 and heterozygous knock-out mice of the ubiquitous 
transmembrane transporter RFC1 resulted in no neural abnormalities (homozygous knock-out is lethal) $[131,134]$. Consequently, the effect of FA supplementation could be to overcome the increased folate requirement of neuroepithelial cells by increasing folate bioavailability.

Folates may be related to NTD risk through their roles in nucleotide synthesis. In fact, in embryos, the rapidly dividing cells of the developing neural tube require the synthesis of large amounts of nucleotides in order to facilitate DNA replication. Barber et al. proposed the hypothesis that if neuroepithelial cells do not have an adequate internal supply of nucleotides, cellular replication will slow down and the development of the neural folds will be retarded [135]. This hypothesis is supported by the Splotch embryos mouse model, which demonstrates a homozygous loss of function mutation in the Pax3 gene. In this model of FA responsive NTDs a deficiency of dTMP biosynthesis has been observed [136]. NTDs in the Splotch model can be rescued by either folic acid [136,137] or thymidine supplementation [136]. This finding suggests that folic acid prevents NTDs by rescuing de novo thymidylate biosynthesis. At the cellular level, the supplementation with FA has an effect on the differentiation, proliferation, and junction formation in neurosphere from splotch embryos that could explain the FA effect on NTD in this model [138]. Impaired thymidylate biosynthesis has also been suggested in another mouse model. In the SHMT1 null mice, embryos exhibit exencephaly consequently to maternal folate deficient diet $[139,140]$. In fact, SHMT1 is involved in the repartition of 1-C unit between thymidylate biosynthesis and homocysteine remethylation. In this mouse model, a potential impaired thymidylate biosynthesis is responsible for NTDs only when associated with maternal folate deficiency. Finally, in the recent MTHFD1 homozygous knock-out mice, which have impaired de novo purine synthesis, neural tube closure was abnormal and embryos died prematurely before E10.5. No NTD was observed in heterozygous mice. Further investigations are required in this model [141]. These three animal models suggest a basis for the role of folates in NTD prevention as a correcting factor for limited nucleotides biosynthesis. Other mechanisms also play a role because in another FA responsive NTD mouse model, the Cited2 deficient mice, thymidylate biosynthesis was not different from wildtype animals [142].

As folates are also involved in the methylation pathway, several authors suggest that disturbed methylation could be responsible for the relation between folate and NTDs. In two studies, Dunlevy et al. disrupted the methylation cycle in cultured mouse embryos with ethionine and cycloleucine or methionine administration during the period of cranial neurulation. This resulted in a specific increased prevalence of NTDs without generalized toxicity such as growth retardation or developmental delay. They conclude that adequate functioning of the methylation cycle is essential for cranial neural tube closure in the mouse $[143,144]$. In another model, Afman et al. observed a delay in the neural tube closure in chick embryos treated with inhibitors of the methylation cycle [145]. Finally, in the Axd and the Amt mouse mutants, being NTD mouse models unresponsive to FA, high doses of methionine given during embryogenesis reduced NTD incidence [146,147]. The gene involved in the Axd mouse model has not yet been identified however the response to methionine suggests the involvement of methylation metabolism in this NTD mouse model. The Amt mouse model is a knock-out for a gene included in the mitochondrial glycine cleavage complex. The inactivation could thus induce a diminution of the mitochondrial and possibly total cellular folates pool leading to decreased bioavailability of 5-MeTHF for the methylation pathway. 
The cellular, molecular or genetic mechanisms by which methylation interfere with neurulation are still largely unknown. Disturbance of the methylation cycle leads to decreased S-adenosylmethionine, increased S-adenosylhomocysteine or decreased S-adenosylmethionine/S-adenosylhomocysteine ratio, all leading to reduced cellular methylation capacity. As previously stated, S-adenosyl methionine is the methyl donor for numerous reactions including protein, lipid, and DNA methylation. On the other hand S-adenosyl-homocysteine is a potent inhibitor of most methyltransferases [126]. One study [148] has suggested that abnormal DNA methylation secondary to remethylation metabolism abnormalities could be involved in the etiology of NTDs. Significant hypomethylation of genomic DNA in the brain have been found in NTDs affected fetuses [149]. Homozygous null embryos for DNMT3B70, coding for one of the enzymes for DNA methylation is responsible for cranial NTDs [150]. Dysregulation of gene expression has also been observed in chick embryos, treated with methylation inhibitors leading to a widening of the anterior neuropore [151]. On the other hand, NTDs are not observed in null embryos for MTHFR, despite a significant reduction in the methylation ratio and global DNA methylation [152]. Bjorklund et al. hypothesized that post translational methylation of proteins from the cytoskeleton required for neural tissue differentiation could be involved in NTDs etiology [153]. In agreement with this hypothesis, methionine has been seen to influence the cytoplasmic distribution of actin and tubulin in neuroepithelial cells during neural tube closure [154].

\section{Arguments for the Implication of Homocysteine, Vitamin B12 and Choline Pathways}

\subsection{Biological and Nutritional Aspects}

\subsubsection{Homocysteine}

Increased total homocysteine has been found in plasma [37,40,155-159] and in amniotic fluid [34,160] of women with NTD affected fetuses or with a history of NTD affected fetuses although these results are inconsistent [34,35,38,161-166]. Increased S-adenosylhomocysteine has also been noted in plasma of women with a history of NTD [40,166]. This results in a decreased S-adenosylmethionine/S-adenosylhomocysteine ratio. Finally, reports have related increased maternal methionine intake with decreased NTD risk [167-169]. Taken together, these results suggest that a disturbed remethylation cycle could be involved in the etiology of NTDs. The influence of methionine intakes and methionine concentrations requires further study.

Levels of homocysteine, increase when the remethylation cycle is disturbed which could itself be toxic. Among the possible mechanisms of homocysteine toxicity, some authors have suggested that homocysteine can act on N-methyl-D-aspartate (NMDA) receptors [170]. Others have hypothesized that homocysteine could have an effect through the increased homocysteinylation of proteins [132]. Several studies in animals have examined the embryotoxicity of homocysteine with conflicting results (reviewed in [171]). Afman et al., have shown a dose dependent closure delay of the anterior neuropore in chick embryos with homocysteine administration [172]. In a comparable experiment, Rosenquist et al. found increased NTDs in mouse embryos treated with homocysteine [173]. In rat embryos, Vanaerts et al. have shown a protective effect of MeTHF, against homocysteine embryotoxicity [174]. 
However, a relationship between homocysteine and neural tube closure was not observed by Greene et al. and Bennett et al., who did not show increased incidence of NTDs in mouse embryos associated with homocysteine exposure [175,176]. Consistent with these findings, the incidence of NTDs is not increased in mice models of hyperhomocysteinemia due to knocking-out of the CBS or MTHFR genes $[152,177]$.

\subsubsection{Vitamin B12}

As for folates, involvement of vitamin B12 in NTD risk has been suggested more than 30 years ago [33]. Recently, Carmichael et al. have shown that a high maternal intake of vitamin B12 is associated with decreased NTD risk [178]. Decreased vitamin B12 [30,31,35,36,42,179] has been found in AFs from women carrying NTDs affected fetuses.

However, data on the impact of maternal blood concentration of B12 are conflicting. Vitamin B12 concentrations were investigated in maternal blood of women carrying a NTD affected fetus or women with a history of NTD affected fetus (reviewed in [180]). Some of these studies have found lower B12 concentrations in these mothers compared to controls [38,156,157,162,164,181-186] while others do not reach statistical significance [30,32,40,159,161,163,165,187-191]. Two meta-analysis have identified an association between low maternal serum vitamin B12 and the risk of NTDs [192,193].

Vitamin B12 bound to transcobalamin (holo-TC) represents the pool of vitamin B12 available for uptake by cells and may represent a better marker of the bioavailability of vitamin B12. Only few studies have measured holo-TC levels in the serum of women with current or previous NTD affected pregnancies and they all found an increased risk of NTDs associated with lower levels of holo-TC [187,194,195].

Elevated methylmalonic acid is a metabolic marker of vitamin B12 insufficiency and is considered a better marker for vitamin B12 deficiency than the measurement of vitamin B12 itself. However, there are too few data to evaluate MMA as a risk factor for NTDs $[188,196]$. Taken together, these data form a body of evidence for the role of vitamin B12 in the etiology of NTD. Whether B12 administration will prevent NTDs has not been studied yet.

\subsubsection{Choline and Betaine}

The role of choline and betaine, which are alternative methyl donors for 5-MeTHF in homocysteine remethylation via betaine-homocysteine methyltransferase, have been investigated in NTDs. The relationship between periconceptional choline and betaine intake and NTD was first investigated by Shaw et al. in pregnant women [197]. Women in the highest quartile of choline intake had a risk reduction of about $50 \%$ compared with those in the lowest quartile. These results were not confirmed in more recent studies from the same group [178,198,199]. However, in Hispanic women a decreased NTD risk was associated with high betaine intakes when they stratified their results for ethnicity [178].

Shaw et al. measured total serum choline, which is mainly constituted by phosphatidylcholine, in pregnant women and found that lower choline was associated with an increased NTD risk in a folate fortified population [200]. For serum betaine no association was found.

The in vitro treatment of mouse embryos with choline uptake or choline metabolism inhibitors was responsible for developmental defects affecting the neural tube and the face [201]. These results 
suggest a putative role of choline metabolism in the etiology of some neural tube defects. More studies are needed to explore the potential role of these methyl donors in NTD risk.

\subsection{Genetic Aspects}

Kang et al. first described a thermolabile variant of the methyltetrahydrofolate reductase (MTHFR) which interfers with folate and remethylation pathways [202]. This variant is due to the 677C > T polymorphisms (Ala222Val, rs1801133) and was first associated with NTD risk by Van der Put et al. [203]. It leads to mild to highly increased plasma total homocysteine concentrations depending on the folate status. Numerous studies have looked at the relationship between NTD risk and genotypes of mothers with children with NTD or children affected with NTD; these are summarized in Table 2. Several meta-analyses have been performed and all have found a significantly increased risk of NTDs associated with MTHFR $677 \mathrm{C}>\mathrm{T}$ either in cases and maternal and even paternal genotypes [12,204-207]. The strength of this association was probably influenced by the ethnic origin of the populations studied and the riboflavin as well as the folate status.

Following the identification of the MTHFR $677 \mathrm{C}>\mathrm{T}$ variant, many potential polymorphisms in genes involved in folate, remethylation, B12 and choline pathways have been explored in NTDs (Table 2). Only few of them may be associated with NTDs risk: MTHFD11958G > A (rs2236225), MTHFD1L (rs3832406), MTHFR 1298A > C (rs1801131), reduced folate carrier A (RFCI) $80 \mathrm{~A}>\mathrm{G}$ (rs1051266) MTR $2756 \mathrm{~A}>\mathrm{G}$ (rs1805087) and MTRR 66A > G (rs1801394).

Interpretation of these studies is complex. For example, the majority of genetic studies in children have been performed on live NTDs-affected children which are in general the mildest affected forms. This may introduce bias. Moreover, it seems that the association between polymorphisms and NTD cases can be influenced by other polymorphisms through gene-gene interactions [208-211], by biological or nutritional factors [211,212] or by folic acid status and supplementation [208,213,214]. The association between polymorphisms and NTDs risk might also be different according to the type or the localization of NTD [160,215,216].

\section{Conclusions}

The protective effect of folic acid on the occurrence and recurrence of NTDs has been clearly demonstrated 20 to 25 years ago. However, the mechanisms underlying folic acid responsive NTDs remains to be elucidated.

It seems that folate status alone is insufficient to cause NTD but that it interacts with multiple genetic and environmental factors that are individually insufficient to cause NTDs. Elegant examples of gene-environment interactions are the SHMT1 and Sploch embryos mouse models in which a folate deficient diet increases NTD frequency [127]. 
Table 2. Polymorphisms from genes involved in folate, choline, B12 vitamin pathway and remethylation cycle that have been studied for their implication in NTDs risk.

\begin{tabular}{|c|c|c|c|c|c|}
\hline & Gene & $\begin{array}{c}\begin{array}{c}\text { Polymorphism(s) } \\
\text { studied }\end{array} \\
\end{array}$ & $\begin{array}{c}\text { Population } \\
\text { studied } \\
\end{array}$ & $\begin{array}{c}\text { Effect on NTD } \\
\text { risk } \\
\end{array}$ & Reference \\
\hline \multirow{9}{*}{ 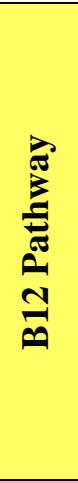 } & \multirow[t]{2}{*}{ CUBN } & rs1907362 & Children & Decreased risk & Franke et al. [217] \\
\hline & & rs4748353 & Children & NS & Franke et al. [217] \\
\hline & \multirow[t]{7}{*}{ TCN2 } & \multirow[t]{3}{*}{ rs 1801198} & Children & NS & Guéant-Rodriguez et al.; Afman et al.; Swanson et al. [218-220] \\
\hline & & & \multirow[t]{2}{*}{ Mothers } & NS & Candito et al.; Afman et al.; Swanson et al. [37,218-220] \\
\hline & & & & Increased risk & Pietrzyk et al. [221] \\
\hline & & rs96067256 & Mothers and & NS & Afman et al.; Swanson et al. [218-220] \\
\hline & & rs4820889 & Children & & \\
\hline & & rs9621049 & & & \\
\hline & & rs1131603 & & & \\
\hline \multirow{7}{*}{ 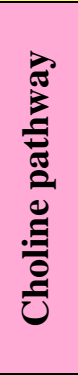 } & \multirow[t]{2}{*}{ BHMT } & \multirow[t]{2}{*}{ rs 3733890} & Children & NS & Zhu et al.; Morin et al. [222,223] \\
\hline & & & Mothers & NS & Morin et al. [222] \\
\hline & BHMT2 & rs626105 & Children & NS & Zhu et al. [223] \\
\hline & \multirow[t]{2}{*}{ CHKA } & hCV1562393C & Children & NS & Enaw et al. [199] \\
\hline & & rs 1562388 & Children & Decreased risk & Enaw et al. [199] \\
\hline & PCYT1A & rs3772109 & Children & NS & Enaw et al. [199] \\
\hline & SARDH & rs573904 & Children & Increased risk & Franke et al. [217] \\
\hline \multirow{8}{*}{ 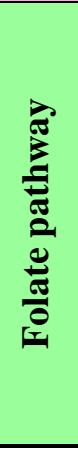 } & \multirow[t]{3}{*}{ DHFR } & 19bp DEL & Fathers & NS & Johnson et al. [224] \\
\hline & & 19bp DEL; 9bp repeat & Children & NS & Johnson et al.; Van der Linden et al.; Doudney et al. [224-226] \\
\hline & & 19bp DEL; 9bp repeat & Mothers & NS & Johnson et al.; Van der Linden et al. [224,226] \\
\hline & \multirow{3}{*}{$\begin{array}{l}\text { Receptor } \\
\text { Folate }\end{array}$} & rs651646 & Fathers & NS & Oleary et al. [227] \\
\hline & & & Children & NS & Oleary et al. [227] \\
\hline & & & Mothers & NS & Oleary et al. [227] \\
\hline & \multirow[t]{2}{*}{ GCPII } & \multirow[t]{2}{*}{ rs61886492 } & Children & NS & Relton et al. [228] \\
\hline & & & Mothers & NS & Morin et al.; Relton et al. [228,229] \\
\hline
\end{tabular}


Table 2. Cont.

\begin{tabular}{|c|c|c|c|c|}
\hline Gene & $\begin{array}{c}\text { Polymorphism(s) } \\
\text { studied }\end{array}$ & $\begin{array}{l}\text { Population } \\
\text { studied }\end{array}$ & $\begin{array}{c}\text { Effect on NTD } \\
\text { risk }\end{array}$ & Reference \\
\hline \multirow[t]{8}{*}{ MTHFD1 } & \multirow[t]{5}{*}{ rs2236225 } & Fathers & NS & Brody et al.; De Marco et al. [230,231] \\
\hline & & Children & NS & Brody et al.; Hol et al.; Van der Linden et al.; Doudney et al. $[225,226,230,232]$ \\
\hline & & & Increased risk & De Marco et al. [231] \\
\hline & & Mothers & Increased risk & Brody et al.; De Marco et al.; Parle McDermott et al. [230,231,233] \\
\hline & & & NS & Van der Linden et al. [234] \\
\hline & \multirow[t]{3}{*}{ rs1950902 } & Fathers & NS & Brody et al. [230] \\
\hline & & Children & NS & Brody et al. [230] \\
\hline & & Mothers & NS & Brody et al. [230] \\
\hline MTHFD1L & rs3832406 & $\begin{array}{l}\text { Children and } \\
\text { mothers }\end{array}$ & $\begin{array}{l}\text { Increased risk } \\
\text { with "allele 1" }\end{array}$ & Parle Mc Dermott et al. [235] \\
\hline \multirow[t]{9}{*}{ MTHFR } & \multirow[t]{3}{*}{ rs2066462 } & Fathers & NS & Morrison et al. [236] \\
\hline & & Children & NS & Morrison et al. [236] \\
\hline & & Mothers & NS & Morrison et al. [236] \\
\hline & \multirow[t]{6}{*}{ rs 1801131} & Fathers & NS & $\begin{array}{l}\text { Van der Put et al.; Volcik et al.; De Marco et al.; Parle McDermott et al.; } \\
\text { Boduroglu et al.; Grandone et al.; Gonzales-Herrera et al.; De Marco et al. } \\
{[163,216,237-242]}\end{array}$ \\
\hline & & & Increased risk & De Marco et al. [239] \\
\hline & & Children & NS & $\begin{array}{l}\text { Van der Put et al.; Volcik et al.; Parle McDermott et al.; Relton et al.; } \\
\text { Boduroglu et al.; Felix et al.; Grandone et al.; Gonzales-Herrera et al.; Doudney et al.; } \\
\text { Behunova et al.; De Marco et al. [162,163,216,228,237,238,240-243] }\end{array}$ \\
\hline & & & Increased risk & De Marcoet al. [239] \\
\hline & & Mothers & NS & $\begin{array}{l}\text { Van der Put et al.; Volcik et al.; Parle McDermott et al.; Gutierrez-Revilla } \\
\text { et al.; Relton et al.; Boduroglu et al.; Grandone et al.; Felix et al.; De Marco } \\
\text { et al. }[162,163,216,228,237,238,241,242,244]\end{array}$ \\
\hline & & & Increased risk & De Marco et al.; Gonzales-Herrera et al.; Candito et al. $[37,239,240]$ \\
\hline
\end{tabular}


Table 2. Cont.

\begin{tabular}{|c|c|c|c|c|}
\hline Gene & $\begin{array}{c}\text { Polymorphism(s) } \\
\text { studied }\end{array}$ & $\begin{array}{c}\text { Population } \\
\text { studied }\end{array}$ & $\begin{array}{l}\text { Effect on } \\
\text { NTD risk } \\
\end{array}$ & Reference \\
\hline \multirow[t]{6}{*}{ MTHFR } & rs1801133 & Fathers & NS & $\begin{array}{l}\text { Papetrou et al.; Van der Put et al.; Morrison et al.; Van der Put et al.; Volcik } \\
\text { et al.; Parle McDermott et al.; Rampersaud et al.; Boduroglu et al.; Grandone } \\
\text { et al. }[163,203,216,236,237,241,242,245,246]\end{array}$ \\
\hline & & & Increased risk & Blom et al. *[12] \\
\hline & & Children & NS & $\begin{array}{l}\text { Papetrou et al.; Mornet et al.; Koch et al.; Morrison et al.; Shaw et al.; } \\
\text { Van der Put et al. *; Christensen et al.; Volcik et al.; Gonzales-Herrera et al.; } \\
\text { Gutierrez-Revilla et al.; Felix et al.; Boduroglu et al.; Doudney et al.; } \\
\text { Behunova et al. [38,162,214,216,225,236,237,242-245,247-249] }\end{array}$ \\
\hline & & & $\begin{array}{l}\text { Increased risk } \\
\\
\text { Decreased risk }\end{array}$ & $\begin{array}{l}\text { Whitehead et al.; Kirke et al., Ou et al.; Van der Put et al. *; De Franchis et al.; } \\
\text { Shields et al.; Botto et al. *; Johanning et al.; Parle McDermott et al.; } \\
\text { Johanning et al.; Pietrzyk et al.; Rampersaud et al.; Kirke et al.; } \\
\text { Relton et al.; Blom et al. *; Grandone et al.; Wenstrom et al. } \\
\text { [12,41,160,163,205,206,241,246,248,250-257] } \\
\text { Guéant-Rodriguez et al. [219] }\end{array}$ \\
\hline & & Mothers & NS & $\begin{array}{l}\text { Papetrou et al.; Morrison et al.; Christensen et al.; Ubbink et al.; Lucock et al.; } \\
\text { Volcik et al.; Gonzales-Herrera et al.; Parle McDermott et al., } \\
\text { Rampersaud et al.; Gutierrez-Revilla et al.; Relton et al.; Boduroglu et al.; } \\
\text { Felix et al.; Grandone et al.; Candito et al.; Shang et al.; Davalos et al. } \\
\text { [37,38,162,163,191,215,216,228,236,237,241,244-247,258,259] }\end{array}$ \\
\hline & & & Increased risk & $\begin{array}{l}\text { Van der Put et al. *; Van der Put et al.; Botto et al. *; Martinez et al.; } \\
\text { Pietrzyk et al.; Yan et al. *; Blom et al. *; Amorim et al. *; Richter et al. } \\
{[12,204-207,252,255,260,261]}\end{array}$ \\
\hline
\end{tabular}


Table 2. Cont.

\begin{tabular}{|c|c|c|c|c|c|}
\hline & Gene & $\begin{array}{l}\text { Polymorphism(s) } \\
\text { studied }\end{array}$ & $\begin{array}{c}\text { Population } \\
\text { studied }\end{array}$ & $\begin{array}{c}\text { Effect on NTD } \\
\text { risk }\end{array}$ & Reference \\
\hline & \multirow[t]{9}{*}{ RFCI } & \multirow[t]{3}{*}{$61 \mathrm{bp}$ repeat } & Fathers & NS & Oleary et al. [262] \\
\hline & & & Children & NS & Oleary et al. [262] \\
\hline & & & Mothers & NS & Oleary et al. [262] \\
\hline & & \multirow[t]{6}{*}{ rs1051266 } & Fathers & NS & $\begin{array}{l}\text { De Marco et al.; Viera et al.; De Marco et al.; Pei et al.; } \\
\text { Oleary et al. [209,238,262-264] }\end{array}$ \\
\hline & & & Children & NS & $\begin{array}{l}\text { De Marco et al.; Shaw et al.; Oleary et al.; Doudney et al.; Wang et al. *; } \\
\text { Relton et al. }[213,225,228,238,262-265]\end{array}$ \\
\hline & & & & Increased risk & De Marco et al.; Pei et al. [209,263] \\
\hline & & & & Decreased risk & Franke et al. [217] \\
\hline & & & Mothers & NS & $\begin{array}{l}\text { De Marco et al.; De Marco et al.; Morin et al.; Oleary et al.; Wang et al. *; } \\
\text { Relton et al. [209,228,229,238,262,265] }\end{array}$ \\
\hline & & & & Increased risk & Pei et al.; Shang et al. $[215,263]$ \\
\hline & \multirow[t]{4}{*}{ SHMT } & \multirow[t]{2}{*}{ rs 1979277} & Children & NS & Heil et al.; Relton et al. $[41,266]$ \\
\hline & & & Mothers & NS & Heil et al.; Relton et al. $[41,266]$ \\
\hline & & \multirow[t]{2}{*}{ delTCTT1721_1724 } & Children & NS & Heil et al. [266] \\
\hline & & & Mothers & NS & Heil et al. [266] \\
\hline \multirow{5}{*}{ 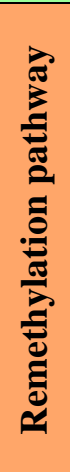 } & \multirow[t]{5}{*}{ MTR } & \multirow[t]{5}{*}{ rs 1805087} & Fathers & NS & Morrison et al.; Oleary et al.; De Marco et al. [236,239,267] \\
\hline & & & Children & NS & $\begin{array}{l}\text { Van der Put et al.; Morrison et al.; Shaw et al.; Johanning et al.; Zhu et al., } \\
\text { Oleary et al.; Doudney et al.; De Marco et al.; Morrison et al. } \\
{[225,238,251,267-271]}\end{array}$ \\
\hline & & & & Decreased risk & Christensen et al. [38] \\
\hline & & & & Increased risk & Guéant-Rodriguez et al. [219] \\
\hline & & & Mothers & NS & $\begin{array}{l}\text { Van der Put et al.; Morrison et al.; Christensen et al.; Doolin et al.; Zhu et al.; } \\
\text { Oleary et al.; Candito et al.; Ouyang et al. *; De Marco et al. } \\
{[37,38,236,239,267,270-273]}\end{array}$ \\
\hline
\end{tabular}


Table 2. Cont

\begin{tabular}{|c|c|c|c|c|}
\hline Gene & $\begin{array}{l}\text { Polymorphism(s) } \\
\text { studied }\end{array}$ & $\begin{array}{l}\text { Population } \\
\text { studied }\end{array}$ & $\begin{array}{l}\text { Effect on NTD } \\
\text { risk }\end{array}$ & Reference \\
\hline \multirow[t]{11}{*}{ MTRR } & \multirow[t]{3}{*}{ rs 162036} & Fathers & NS & Oleary et al. [267] \\
\hline & & Children & NS & Oleary et al. [267] \\
\hline & & Mothers & NS & Oleary et al. [267] \\
\hline & \multirow[t]{3}{*}{ rs 1532268} & Fathers & NS & Oleary et al. [267] \\
\hline & & Children & NS & Oleary et al. [267] \\
\hline & & Mothers & NS & Oleary et al. [267] \\
\hline & \multirow[t]{5}{*}{ rs1801394 } & Fathers & Increased risk & Oleary et al. [267] \\
\hline & & \multirow[t]{2}{*}{ Children } & NS & $\begin{array}{l}\text { Wilson et al.; Oleary et al.; Van der Linden et al.; Doudney et al. } \\
{[211,214,225,267]}\end{array}$ \\
\hline & & & Increased risk & Pietrzyk et al.; Zhu et al.; Relton et al. [228,255,271] \\
\hline & & \multirow[t]{2}{*}{ Mothers } & NS & Wilson et al.; Relton et al.; Oleary et al. [211,228,267] \\
\hline & & & Increased risk & $\begin{array}{l}\text { Doolin et al.; Pietrzyk et al.; Zhu et al.; Van der Linden et al.; Candito et al.; } \\
\text { Ouyang et al. *, Franke et al. }[37,212,217,255,271-273]\end{array}$ \\
\hline
\end{tabular}

* This reference is a meta-analyse; NS: no significant association found. 
Besides the role of folates in nucleotides biosynthesis, there are data pointing to the involvement of transmethylation by S-adenosylmethionine for the folic acid preventive effect as illustrated by methionine responsive mouse models. Choline, betaine and B12 metabolism, which is essential for optimal methylation, is emerging as a potential risk factor (Figure 4). The accumulation of scientific evidence warrants intervention studies based on periconceptional supplementation of vitamin B12 [274], choline or betaine [275] in the prevention of NTDs. Due to the multifactorial nature of the etiology of sporadic NTDs. The interpretation of these data will be challenging and large cohorts are needed to observe a potential effect. This underlines the need for international collaborations. Intervention studies are now needed to affirm or refute the hypothesis that choline, betaine or vitamin B12 supplementation has a role in the prevention of NTDs.

Figure 4. Nutritional, biological, and genetic risk factors of folate, B12 vitamin, remethylation and choline metabolisms that have (potentially) been related with NTDs risk. MMA: Methylmalonic acid, holo-TC: holo-transcobalamin.

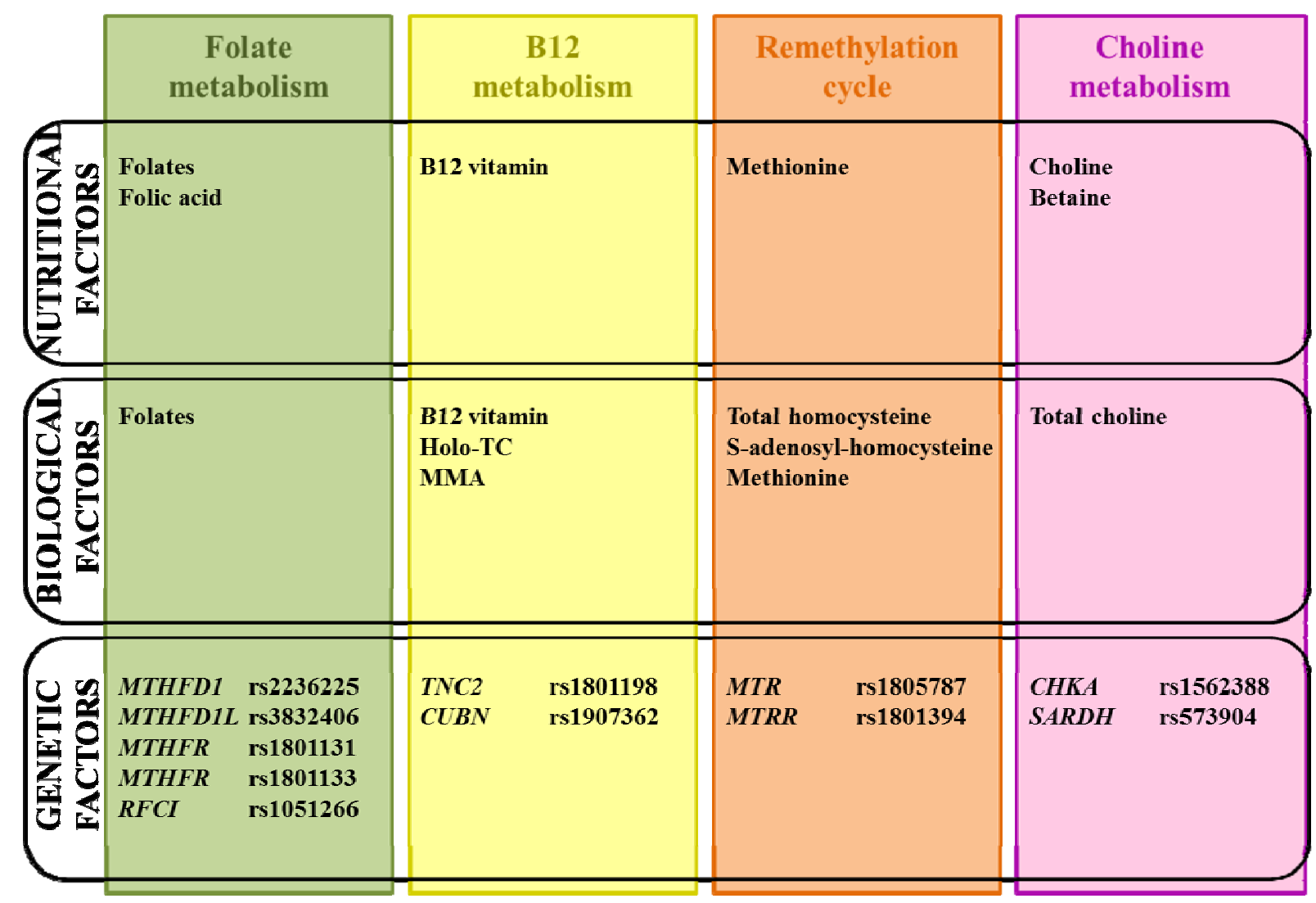

\section{Acknowledgments}

The authors would like to thank Peter Jones for revision of this manuscript.

\section{Conflicts of Interest}

The authors declare no conflict of interest. 


\section{References}

1. Au, K.S.; Ashley-Koch, A.; Northrup, H. Epidemiologic and genetic aspects of spina bifida and other neural tube defects. Dev. Disabil. Res. Rev. 2010, 16, 6-15.

2. Northrup, H.; Volcik, K.A. Spina bifida and other neural tube defects. Curr. Probl. Pediatr. 2000, 30, 313-332.

3. Sadler, T.W. Embryology of neural tube development. Am. J. Med. Genet. C Semin. Med. Genet. 2005, 135C, 2-8.

4. Thompson, D.N. Postnatal management and outcome for neural tube defects including spina bifida and encephalocoeles. Prenat. Diagn. 2009, 29, 412-419.

5. Waitzman, N.J.; Romano, P.S.; Scheffler, R.M. Estimates of the economic costs of birth defects. Inquiry 1994, 31, 188-205.

6. Yi, Y.; Lindemann, M.; Colligs, A.; Snowball, C. Economic burden of neural tube defects and impact of prevention with folic acid: A literature review. Eur. J. Pediatr. 2011, 170, 1391-1400.

7. Lynch, S.A. Non-multifactorial neural tube defects. Am. J. Med. Genet. C Semin. Med. Genet. 2005, 135C, 69-76.

8. Frey, L.; Hauser, W.A. Epidemiology of neural tube defects. Epilepsia 2003, 44, 4-13.

9. Greene, N.D.; Stanier, P.; Copp, A.J. Genetics of human neural tube defects. Hum. Mol. Genet. 2009, 18, R113-R129.

10. Hibbard, B.M.; Hibbard, E.D.; Jeffcoate, T.N. Folic acid and reproduction. Acta Obstet. Gynecol. Scand. 1965, 44, 375-400.

11. Blom, H.J. Folic acid, methylation and neural tube closure in humans. Birth Defects Res. 2009, 85, 295-302.

12. Blom, H.J.; Shaw, G.M.; den Heijer, M.; Finnell, R.H. Neural tube defects and folate: Case far from closed. Nat. Rev. Neurosci. 2006, 7, 724-731.

13. Blom, H.J.; Smulders, Y. Overview of homocysteine and folate metabolism. With special references to cardiovascular disease and neural tube defects. J. Inherit. Metab. Dis. 2011, 34, 75-81.

14. Botto, L.D.; Moore, C.A.; Khoury, M.J.; Erickson, J.D. Neural-tube defects. N. Engl. J. Med. 1999, 341, 1509-1519.

15. De Marco, P.; Merello, E.; Cama, A.; Kibar, Z.; Capra, V. Human neural tube defects: Genetic causes and prevention. Biofactors 2011, 37, 261-268.

16. Van der Put, N.M.; van Straaten, H.W.; Trijbels, F.J.; Blom, H.J. Folate, homocysteine and neural tube defects: An overview. Exp. Biol. Med. 2001, 226, 243-270.

17. Copp, A.J.; Greene, N.D.; Murdoch, J.N. The genetic basis of mammalian neurulation. Nat. Rev. Genet. 2003, 4, 784-793.

18. Detrait, E.R.; George, T.M.; Etchevers, H.C.; Gilbert, J.R.; Vekemans, M.; Speer, M.C. Human neural tube defects: Developmental biology, epidemiology, and genetics. Neurotoxicol. Teratol. 2005, 27, 515-524.

19. Wallingford, J.B. Neural tube closure and neural tube defects: Studies in animal models reveal known knowns and known unknowns. Am. J. Med. Genet. C Semin. Med. Genet. 2005, 135C, 59-68. 
20. Copp, A.J. Neurulation in the cranial region-Normal and abnormal. J. Anat. 2005, 207, 623-635.

21. Padmanabhan, R. Etiology, pathogenesis and prevention of neural tube defects. Congenit. Anom. 2006, 46, 55-67.

22. Michie, C.A. Neural tube defects in 18th century. Lancet 1991, 337, 504, doi:10.1016/ 0140-6736(91)93453-G.

23. Smithells, R.W.; Sheppard, S.; Schorah, C.J. Vitamin dificiencies and neural tube defects. Arch. Dis. Child. 1976, 51, 944-950.

24. Emery, A.E.; Timson, J.; Watson-Williams, E.J. Pathogenesis of spina bifida. Lancet 1969, 2, 909-910.

25. Hibbard, B.M. The role of folic acid in pregnancy; With particular reference to anaemia, abruption and abortion. J. Obstet. Gynaecol. Br. Commonw. 1964, 71, 529-542.

26. Smithells, R.W. Multivitamins for the prevention of neural tube defects. How convincing is the evidence? Drugs 1989, 38, 849-854.

27. Smithells, R.W.; Nevin, N.C.; Seller, M.J.; Sheppard, S.; Harris, R.; Read, A.P.; Fielding, D.W.; Walker, S.; Schorah, C.J.; Wild, J. Further experience of vitamin supplementation for prevention of neural tube defect recurrences. Lancet 1983, 1, 1027-1031.

28. Smithells, R.W.; Sheppard, S. Possible prevention of neural-tube defects by periconceptional vitamin supplementation. Lancet 1980, 1, 647, doi:10.1016/S0140-6736(80)90886-7.

29. Smithells, R.W.; Sheppard, S.; Schorah, C.J.; Seller, M.J.; Nevin, N.C.; Harris, R.; Read, A.P.; Fielding, D.W. Apparent prevention of neural tube defects by periconceptional vitamin supplementation. Arch. Dis. Child. 1981, 56, 911-918.

30. Economides, D.L.; Ferguson, J.; Mackenzie, I.Z.; Darley, J.; Ware, I.I.; Holmes-Siedle, M. Folate and vitamin B12 concentrations in maternal and fetal blood, and amniotic fluid in second trimester pregnancies complicated by neural tube defects. Br. J. Obstet. Gynaecol. 1992, 99, 23-25.

31. Gardiki-Kouidou, P.; Seller, M.J. Amniotic fluid folate, vitamin B12 and transcobalamins in neural tube defects. Clin. Genet. 1988, 33, 441-448.

32. Molloy, A.M.; Kirke, P.; Hillary, I.; Weir, D.G.; Scott, J.M. Maternal serum folate and vitamin B12 concentrations in pregnancies associated with neural tube defects. Arch. Dis. Child. 1985, 60, 660-665.

33. Schorah, C.J.; Smithells, R.W.; Scott, J. Vitamin B12 and anencephaly. Lancet 1980, 1, 880, doi:10.1016/S0140-6736(80)91381-1.

34. Steegers-Theunissen, R.P.; Boers, G.H.; Blom, H.J.; Nijhuis, J.G.; Thomas, C.M.; Borm, G.F.; Eskes, T.K. Neural tube defects and elevated homocysteine levels in amniotic fluid. Am. J. Obstet. Gynecol. 1995, 172, 1436-1441.

35. Steen, M.T.; Boddie, A.M.; Fisher, A.J.; Macmahon, W.; Saxe, D.; Sullivan, K.M.; Dembure, P.P.; Elsas, L.J. Neural-tube defects are associated with low concentrations of cobalamin (vitamin B12) in amniotic fluid. Prenat. Diagn. 1998, 18, 545-555.

36. Weekes, E.W.; Tamura, T.; Davis, R.O.; Birch, R.; Vaughn, W.H.; Franklin, J.C.; Barganier, C.; Cosper, P.; Finley, S.C.; Finley, W.H. Nutrient levels in amniotic fluid from women with normal and neural tube defect pregnancies. Biol. Neonate 1992, 61, 226-231. 
37. Candito, M.; Rivet, R.; Herbeth, B.; Boisson, C.; Rudigoz, R.C.; Luton, D.; Journel, H.; Oury, J.F.; Roux, F.; Saura, R.; et al. Nutritional and genetic determinants of vitamin B and homocysteine metabolisms in neural tube defects: A multicenter case-control study. Am. J. Med. Genet. 2008, 146A, 1128-1133.

38. Christensen, B.; Arbour, L.; Tran, P.; Leclerc, D.; Sabbaghian, N.; Platt, R.; Gilfix, B.M.; Rosenblatt, D.S.; Gravel, R.A.; Forbes, P.; et al. Genetic polymorphisms in methylenetetrahydrofolate reductase and methionine synthase, folate levels in red blood cells, and risk of neural tube defects. Am. J. Med. Genet. 1999, 84, 151-157.

39. Wald, N.J.; Hackshaw, A.D.; Stone, R.; Sourial, N.A. Blood folic acid and vitamin B12 in relation to neural tube defects. Br. J. Obstet. Gynaecol. 1996, 103, 319-324.

40. Zhao, W.; Mosley, B.S.; Cleves, M.A.; Melnyk, S.; James, S.J.; Hobbs, C.A. Neural tube defects and maternal biomarkers of folate, homocysteine, and glutathione metabolism. Birth Defects Res. 2006, 76, 230-236.

41. Relton, C.L.; Wilding, C.S.; Laffling, A.J.; Jonas, P.A.; Burgess, T.; Binks, K.; Tawn, E.J.; Burn, J. Low erythrocyte folate status and polymorphic variation in folate-related genes are associated with risk of neural tube defect pregnancy. Mol. Genet. Metab. 2004, 81, 273-281.

42. Dawson, E.B.; Evans, D.R.; Harris, W.A.; van Hook, J.W. Amniotic fluid B12, calcium, and lead levels associated with neural tube defects. Am. J. Perinatol. 1999, 16, 373-378.

43. Pitkin, R.M. Folate and neural tube defects. Am. J. Clin. Nutr. 2007, 85, 285S-288S.

44. Vergel, R.G.; Sanchez, L.R.; Heredero, B.L.; Rodriguez, P.L.; Martinez, A.J. Primary prevention of neural tube defects with folic acid supplementation: Cuban experience. Prenat. Diagn. 1990, 10, 149-152.

45. Bower, C.; Stanley, F.J. Dietary folate as a risk factor for neural-tube defects: Evidence from a case-control study in Western Australia. Med. J. Aust. 1989, 150, 613-619.

46. McMahon, D.M.; Liu, J.; Zhang, H.; Torres, M.E.; Best, R.G. Maternal obesity, folate intake, and neural tube defects in offspring. Birth Defects Res. 2013, 97, 115-122.

47. Milunsky, A.; Jick, H.; Jick, S.S.; Bruell, C.L.; MacLaughlin, D.S.; Rothman, K.J.; Willett, W. Multivitamin/folic acid supplementation in early pregnancy reduces the prevalence of neural tube defects. JAMA 1989, 262, 2847-2852.

48. Mulinare, J.; Cordero, J.F.; Erickson, J.D.; Berry, R.J. Periconceptional use of multivitamins and the occurrence of neural tube defects. JAMA 1988, 260, 3141-3145.

49. Shaw, G.M.; O’Malley, C.D.; Wasserman, C.R.; Tolarova, M.M.; Lammer, E.J. Maternal periconceptional use of multivitamins and reduced risk for conotruncal heart defects and limb deficiencies among offspring. Am. J. Med. Genet. 1995, 59, 536-545.

50. Shaw, G.M.; Schaffer, D.; Velie, E.M.; Morland, K.; Harris, J.A. Periconceptional vitamin use, dietary folate, and the occurrence of neural tube defects. Epidemiology 1995, 6, 219-226.

51. Werler, M.M.; Shapiro, S.; Mitchell, A.A. Periconceptional folic acid exposure and risk of occurrent neural tube defects. JAMA 1993, 269, 1257-1261.

52. Mills, J.L.; Rhoads, G.G.; Simpson, J.L.; Cunningham, G.C.; Conley, M.R.; Lassman, M.R.; Walden, M.E.; Depp, O.R.; Hoffman, H.J. The absence of a relation between the periconceptional use of vitamins and neural-tube defects. National institute of child health and human development neural tube defects study group. N. Engl. J. Med. 1989, 321, 430-435. 
53. Wright, M.E. A case-control study of maternal nutrition and neural tube defects in Northern Ireland. Midwifery 1995, 11, 146-152.

54. Laurence, K.M.; James, N.; Miller, M.H.; Tennant, G.B.; Campbell, H. Double-blind randomised controlled trial of folate treatment before conception to prevent recurrence of neural-tube defects. Br. Med. J. 1981, 282, 1509-1511.

55. Wald, N.J.; Polani, P.E. Neural-tube defects and vitamins: The need for a randomized clinical trial. Br. J. Obstet. Gynaecol. 1984, 91, 516-523.

56. Medical Research Council vitamin study group. Prevention of neural tube defects: Results of the medical research council vitamin study. Lancet 1991, 338, 131-137.

57. Czeizel, A.E.; Dudas, I. Prevention of the first occurrence of neural-tube defects by periconceptional vitamin supplementation. N. Engl. J. Med. 1992, 327, 1832-1835.

58. Berry, R.J.; Li, Z.; Erickson, J.D.; Li, S.; Moore, C.A.; Wang, H.; Mulinare, J.; Zhao, P.; Wong, L.Y.; Gindler, J.; et al. Prevention of neural-tube defects with folic acid in China. China-U.S. Collaborative project for neural tube defect prevention. N. Engl. J. Med. 1999, 341, 1485-1490.

59. U.S. Department of Health and Human Services Public Health Service Centers for Disease Control. Recommendations for the use of folic acid to reduce the number of cases of spina bifida and other neural tube defects. MMWR Recomm. Rep. 1992, 41, 1-7.

60. Stevenson, R.E.; Allen, W.P.; Pai, G.S.; Best, R.; Seaver, L.H.; Dean, J.; Thompson, S. Decline in prevalence of neural tube defects in a high-risk region of the United States. Pediatrics 2000, 106, 677-683.

61. Food and Drug Administration. Food standards: Amendment of standards of identity for enriched grain products to require addition of folic acid. Fed. Regist. 1996, 61, 8781-8797.

62. Bailey, L.B. Folate and vitamin B12 recommended intakes and status in the United States. Nutr. Rev. 2004, 62, S14-S20.

63. U.S. Department of Health and Human Services Public Health Service Centers for Disease Control. Folate status in women of childbearing age, by race/ethnicity_United States, 19992000. MMWR Morb. Mortal. Wkly. Rep. 2002, 51, 808-810.

64. Liu, S.; West, R.; Randell, E.; Longerich, L.; O’Connor, K.S.; Scott, H.; Crowley, M.; Lam, A.; Prabhakaran, V.; McCourt, C. A comprehensive evaluation of food fortification with folic acid for the primary prevention of neural tube defects. BMC Pregnancy Childbirth 2004, 4, 20-29.

65. Ray, J.G. Folic acid food fortification in Canada. Nutr. Rev. 2004, 62, S35-S39.

66. Wald, N.J.; Law, M.R.; Morris, J.K.; Wald, D.S. Quantifying the effect of folic acid. Lancet 2001, 358, 2069-2073.

67. Jacques, P.F.; Selhub, J.; Bostom, A.G.; Wilson, P.W.; Rosenberg, I.H. The effect of folic acid fortification on plasma folate and total homocysteine concentrations. N. Engl. J. Med. 1999, 340, 1449-1454.

68. Rader, J.I. Folic acid fortification, folate status and plasma homocysteine. J. Nutr. 2002, 132, 2466S-2470S.

69. De Wals, P.; Tairou, F.; van Allen, M.I.; Uh, S.H.; Lowry, R.B.; Sibbald, B.; Evans, J.A.; van den Hof, M.C.; Zimmer, P.; Crowley, M.; et al. Reduction in neural-tube defects after folic acid fortification in Canada. N. Engl. J. Med. 2007, 357, 135-142. 
70. Williams, L.J.; Rasmussen, S.A.; Flores, A.; Kirby, R.S.; Edmonds, L.D. Decline in the prevalence of spina bifida and anencephaly by race/ethnicity: 1995-2002. Pediatrics 2005, 116, $580-586$.

71. Flour Fortification Initiative. Country Profile. Available online: http://www.ffinetwork.org/ country_profiles/index.php (accessed on 1 July 2013).

72. Ray, J.G.; Meier, C.; Vermeulen, M.J.; Boss, S.; Wyatt, P.R.; Cole, D.E. Association of neural tube defects and folic acid food fortification in Canada. Lancet 2002, 360, 2047-2048.

73. Honein, M.A.; Paulozzi, L.J.; Mathews, T.J.; Erickson, J.D.; Wong, L.Y. Impact of folic acid fortification of the US food supply on the occurrence of neural tube defects. JAMA 2001, 285, 2981-2986.

74. Persad, V.L.; van den Hof, M.C.; Dube, J.M.; Zimmer, P. Incidence of open neural tube defects in Nova Scotia after folic acid fortification. CMAJ 2002, 167, 241-245.

75. Williams, L.J.; Mai, C.T.; Edmonds, L.D.; Shaw, G.M.; Kirby, R.S.; Hobbs, C.A.; Sever, L.E.; Miller, L.A.; Meaney, F.J.; Levitt, M. Prevalence of spina bifida and anencephaly during the transition to mandatory folic acid fortification in the United States. Teratology 2002, 66, 33-39.

76. De Wals, P.; Rusen, I.D.; Lee, N.S.; Morin, P.; Niyonsenga, T. Trend in prevalence of neural tube defects in Quebec. Birth Defects Res. 2003, 67, 919-923.

77. Palomaki, G.E.; Williams, J.; Haddow, J.E. Comparing the observed and predicted effectiveness of folic acid fortification in preventing neural tube defects. J. Med. Screen. 2003, 10, 52-53.

78. Lambert-Messerlian, G.; Halliday, J.; Williams, J.; Cain, R.; Msall, M.E.; Palomaki, G.E.; Canick, J.A. Effect of folic acid fortification on prevalence of neural tube defects in Rhode Island. J. Med. Screen. 2004, 11, 106-107.

79. Simmons, C.J.; Mosley, B.S.; Fulton-Bond, C.A.; Hobbs, C.A. Birth defects in Arkansas: Is folic acid fortification making a difference? Birth Defects Res. 2004, 70, 559-564.

80. Chen, L.T.; Rivera, M.A. The Costa Rican experience: Reduction of neural tube defects following food fortification programs. Nutr. Rev. 2004, 62, S40-S43.

81. Hertrampf, E.; Cortes, F. Folic acid fortification of wheat flour: Chile. Nutr. Rev. 2004, 62, S44-S48.

82. Lopez-Camelo, J.S.; Orioli, I.M.; da Graca Dutra, M.; Nazer-Herrera, J.; Rivera, N.; Ojeda, M.E.; Canessa, A.; Wettig, E.; Fontannaz, A.M.; Mellado, C.; et al. Reduction of birth prevalence rates of neural tube defects after folic acid fortification in Chile. Am. J. Med. Genet. A 2005, 135, $120-125$.

83. Canfield, M.A.; Collins, J.S.; Botto, L.D.; Williams, L.J.; Mai, C.T.; Kirby, R.S.; Pearson, K.; Devine, O.; Mulinare, J. Changes in the birth prevalence of selected birth defects after grain fortification with folic acid in the United States: Findings from a multi-state population-based study. Birth Defects Res. 2005, 73, 679-689.

84. Chen, B.H.; Carmichael, S.L.; Selvin, S.; Abrams, B.; Shaw, G.M. NTD prevalences in central California before and after folic acid fortification. Birth Defects Res. 2008, 82, 547-552.

85. Sayed, A.R.; Bourne, D.; Pattinson, R.; Nixon, J.; Henderson, B. Decline in the prevalence of neural tube defects following folic acid fortification and its cost-benefit in South Africa. Birth Defects Res. 2008, 82, 211-216. 
86. Amarin, Z.O.; Obeidat, A.Z. Effect of folic acid fortification on the incidence of neural tube defects. Paediatr. Perinat. Epidemiol. 2010, 24, 349-351.

87. Romano, P.S.; Waitzman, N.J.; Scheffler, R.M.; Pi, R.D. Folic acid fortification of grain: An economic analysis. Am. J. Public Health 1995, 85, 667-676.

88. Grosse, S.D.; Ouyang, L.; Collins, J.S.; Green, D.; Dean, J.H.; Stevenson, R.E. Economic evaluation of a neural tube defect recurrence-prevention program. Am. J. Prev. Med. 2008, 35, 572-577.

89. EFSA, E.F.S.A. Folic Acid: An Update on Scientific Developments. Available online: http://www.efsa.europa.eu/en/home/publication/efsafolicacid.pdf (accessed on 1 July 2013).

90. Brent, R.L.; Oakley, G.P., Jr. The food and drug administration must require the addition of more folic acid in "Enriched" Flour and other grains. Pediatrics 2005, 116, 753-755.

91. Brent, R.L.; Oakley, G.P., Jr. Triumph and/or tragedy: The present food and drug administration program of enriching grains with folic acid. Pediatrics 2006, 117, 930-932.

92. Brent, R.L.; Oakley, G.P., Jr.; Mattison, D.R. The unnecessary epidemic of folic acid-preventable spina bifida and anencephaly. Pediatrics 2000, 106, 825-827.

93. Oakley, G.P., Jr. Let's increase folic acid fortification and include vitamin B-12. Am. J. Clin. Nutr. 1997, 65, 1889-1890.

94. Daly, L.E.; Kirke, P.N.; Molloy, A.; Weir, D.G.; Scott, J.M. Folate levels and neural tube defects. Implications for prevention. JAMA 1995, 274, 1698-1702.

95. Moore, L.L.; Bradlee, M.L.; Singer, M.R.; Rothman, K.J.; Milunsky, A. Folate intake and the risk of neural tube defects: An estimation of dose-response. Epidemiology 2003, 14, 200-205.

96. Wald, N.J. Folic acid and the prevention of neural-tube defects. N. Engl. J. Med. 2004, 350, 101-103.

97. Agopian, A.J.; Tinker, S.C.; Lupo, P.J.; Canfield, M.A.; Mitchell, L.E. Proportion of neural tube defects attributable to known risk factors. Birth Defects Res. 2013, 97, 42-46.

98. Heseker, H.B.; Mason, J.B.; Selhub, J.; Rosenberg, I.H.; Jacques, P.F. Not all cases of neural-tube defect can be prevented by increasing the intake of folic acid. Br. J. Nutr. 2009, 102, 173-180.

99. Crider, K.S.; Bailey, L.B.; Berry, R.J. Folic acid food fortification-its history, effect, concerns, and future directions. Nutrients 2011, 3, 370-384.

100. Mills, J.L. Fortification of foods with folic acid-How much is enough? N. Engl. J. Med. 2000, 342, 1442-1445.

101. Osterhues, A.; Holzgreve, W.; Michels, K.B. Shall we put the world on folate? Lancet 2009, 374, 959-961.

102. Clarke, R.; Halsey, J.; Lewington, S.; Lonn, E.; Armitage, J.; Manson, J.E.; Bonaa, K.H.; Spence, J.D.; Nygard, O.; Jamison, R.; et al. Effects of lowering homocysteine levels with B vitamins on cardiovascular disease, cancer, and cause-specific mortality: Meta-analysis of 8 randomized trials involving 37485 individuals. Arch. Intern. Med. 2010, 170, 1622-1631.

103. Edwards, B.K.; Ward, E.; Kohler, B.A.; Eheman, C.; Zauber, A.G.; Anderson, R.N.; Jemal, A.; Schymura, M.J.; Lansdorp-Vogelaar, I.; Seeff, L.C.; et al. Annual report to the nation on the status of cancer, 1975-2006, featuring colorectal cancer trends and impact of interventions (risk factors, screening, and treatment) to reduce future rates. Cancer 2010, 116, 544-573. 
104. Marean, A.; Graf, A.; Zhang, Y.; Niswander, L. Folic acid supplementation can adversely affect murine neural tube closure and embryonic survival. Hum. Mol. Genet. 2011, 20, 3678-3683.

105. Pickell, L.; Brown, K.; Li, D.; Wang, X.L.; Deng, L.; Wu, Q.; Selhub, J.; Luo, L.; Jerome-Majewska, L.; Rozen, R. High intake of folic acid disrupts embryonic development in mice. Birth Defects Res. 2011, 91, 8-19.

106. Botto, L.D.; Lisi, A.; Robert-Gnansia, E.; Erickson, J.D.; Vollset, S.E.; Mastroiacovo, P.; Botting, B.; Cocchi, G.; de Vigan, C.; de Walle, H.; et al. International retrospective cohort study of neural tube defects in relation to folic acid recommendations: Are the recommendations working? BMJ 2005, 330, 571-576.

107. EUROCAT Folic Acid Working Group. Prevention of Neural Tube Defects by Periconceptional Folic Acid Supplementation in Europe. Available online: http://www.eurocat-network.eu/ content/Special-Report-NTD-3rdEd-Part-I.pdf (accessed on 1 July 2013).

108. Botto, L.D.; Lisi, A.; Bower, C.; Canfield, M.A.; Dattani, N.; de Vigan, C.; de Walle, H.; Erickson, D.J.; Halliday, J.; Irgens, L.M.; et al. Trends of selected malformations in relation to folic acid recommendations and fortification: An international assessment. Birth Defects Res. 2006, 76, 693-705.

109. Stoll, C.; Alembik, Y.; Dott, B. Are the recommendations on the prevention of neural tube defects working? Eur. J. Med. Genet. 2006, 49, 461-465.

110. Rofail, D.; Colligs, A.; Abetz, L.; Lindemann, M.; Maguire, L. Factors contributing to the success of folic acid public health campaigns. J. Public Health 2012, 34, 90-99.

111. Bitzer, J.; von Stenglin, A.; Bannemerschult, R. Women's awareness and periconceptional use of folic acid: Data from a large European survey. Int. J. Womens Health 2013, 5, 201-213.

112. Michie, C.A.; Narang, I.; Rogers, J.; Robinson, A. Folate supplementation and neural-tube defects. Lancet 2000, 355, 147, doi:10.1016/S0140-6736(00)72063-8.

113. Ren, A.; Zhang, L.; Li, Z.; Hao, L.; Tian, Y. Awareness and use of folic acid, and blood folate concentrations among pregnant women in northern China-An area with a high prevalence of neural tube defects. Reprod. Toxicol. 2006, 22, 431-436.

114. Ray, J.G.; Singh, G.; Burrows, R.F. Evidence for suboptimal use of periconceptional folic acid supplements globally. BJOG 2004, 111, 399-408.

115. Abramsky, L.; Dolk, H. Should Europe fortify a staple food with folic acid? Lancet 2007, 369, 641-642.

116. Czeizel, A.E. Folic acid: A public-health challenge. Lancet 2006, 367, 2056, doi:10.1016/S0 140-6736(06)68916-2.

117. Mastroiacovo, P.; Leoncini, E. More folic acid, the five questions: Why, who, when, how much, and how. Biofactors 2011, 37, 272-279.

118. Taruscio, D.; Carbone, P.; Granata, O.; Baldi, F.; Mantovani, A. Folic acid and primary prevention of birth defects. Biofactors 2011, 37, 280-284.

119. Beaudin, A.E.; Stover, P.J. Insights into metabolic mechanisms underlying folate-responsive neural tube defects: A minireview. Birth Defects Res. 2009, 85, 274-284.

120. Stover, P.J. Physiology of folate and vitamin B12 in health and disease. Nutr. Rev. 2004, 62, S3-S12. 
121. Appling, D.R. Compartmentation of folate-mediated one-carbon metabolism in eukaryotes. FASEB J. 1991, 5, 2645-2651.

122. Stover, P.J.; Field, M.S. Trafficking of intracellular folates. Adv. Nutr. 2011, 2, 325-331.

123. Holm, P.I.; Ueland, P.M.; Vollset, S.E.; Midttun, O.; Blom, H.J.; Keijzer, M.B.; den Heijer, M. Betaine and folate status as cooperative determinants of plasma homocysteine in humans. Arterioscler. Thromb. Vasc. Biol. 2005, 25, 379-385.

124. Imbard, A.; Smulders, Y.M.; Barto, R.; Smith, D.E.; Kok, R.M.; Jakobs, C.; Blom, H.J. Plasma choline and betaine correlate with serum folate, plasma S-adenosyl-methionine and S-adenosyl-homocysteine in healthy volunteers. Clin. Chem. Lab. Med. 2012, 51, 683-692.

125. Melse-Boonstra, A.; Holm, P.I.; Ueland, P.M.; Olthof, M.; Clarke, R.; Verhoef, P. Betaine concentration as a determinant of fasting total homocysteine concentrations and the effect of folic acid supplementation on betaine concentrations. Am. J. Clin. Nutr. 2005, 81, 1378-1382.

126. Finkelstein, J.D. Metabolic regulatory properties of S-adenosylmethionine and S-adenosylhomocysteine. Clin. Chem. Lab. Med. 2007, 45, 1694-1699.

127. Burren, K.A.; Savery, D.; Massa, V.; Kok, R.M.; Scott, J.M.; Blom, H.J.; Copp, A.J.; Greene, N.D. Gene-environment interactions in the causation of neural tube defects: Folate deficiency increases susceptibility conferred by loss of Pax3 function. Hum. Mol. Genet. 2008, 17, 3675-3685.

128. Heid, M.K.; Bills, N.D.; Hinrichs, S.H.; Clifford, A.J. Folate deficiency alone does not produce neural tube defects in mice. J. Nutr. 1992, 122, 888-894.

129. Rothenberg, S.P.; da Costa, M.P.; Sequeira, J.M.; Cracco, J.; Roberts, J.L.; Weedon, J.; Quadros, E.V. Autoantibodies against folate receptors in women with a pregnancy complicated by a neural-tube defect. N. Engl. J. Med. 2004, 350, 134-142.

130. Obican, S.G.; Finnell, R.H.; Mills, J.L.; Shaw, G.M.; Scialli, A.R. Folic acid in early pregnancy: A public health success story. FASEB J. 2010, 24, 4167-4174.

131. Piedrahita, J.A.; Oetama, B.; Bennett, G.D.; van Waes, J.; Kamen, B.A.; Richardson, J.; Lacey, S.W.; Anderson, R.G.; Finnell, R.H. Mice lacking the folic acid-binding protein Folbp1 are defective in early embryonic development. Nat. Genet. 1999, 23, 228-232.

132. Taparia, S.; Gelineau-van Waes, J.; Rosenquist, T.H.; Finnell, R.H. Importance of folate-homocysteine homeostasis during early embryonic development. Clin. Chem. Lab. Med. 2007, 45, 1717-1727.

133. Spiegelstein, O.; Mitchell, L.E.; Merriweather, M.Y.; Wicker, N.J.; Zhang, Q.; Lammer, E.J.; Finnell, R.H. Embryonic development of folate binding protein-1 (Folbp1) knockout mice: Effects of the chemical form, dose, and timing of maternal folate supplementation. Dev. Dyn. 2004, 231, 221-231.

134. Zhao, R.; Russell, R.G.; Wang, Y.; Liu, L.; Gao, F.; Kneitz, B.; Edelmann, W.; Goldman, I.D. Rescue of embryonic lethality in reduced folate carrier-deficient mice by maternal folic acid supplementation reveals early neonatal failure of hematopoietic organs. J. Biol. Chem. 2001, 276, 10224-10228.

135. Barber, R.C.; Lammer, E.J.; Shaw, G.M.; Greer, K.A.; Finnell, R.H. The role of folate transport and metabolism in neural tube defect risk. Mol. Genet. Metab. 1999, 66, 1-9. 
136. Fleming, A.; Copp, A.J. Embryonic folate metabolism and mouse neural tube defects. Science 1998, 280, 2107-2109.

137. Wlodarczyk, B.J.; Tang, L.S.; Triplett, A.; Aleman, F.; Finnell, R.H. Spontaneous neural tube defects in splotch mice supplemented with selected micronutrients. Toxicol. Appl. Pharmacol. 2006, 213, 55-63.

138. Ichi, S.; Nakazaki, H.; Boshnjaku, V.; Singh, R.M.; Mania-Farnell, B.; Xi, G.; McLone, D.G.; Tomita, T.; Mayanil, C.S. Fetal neural tube stem cells from Pax3 mutant mice proliferate, differentiate, and form synaptic connections when stimulated with folic acid. Stem. Cells Dev. 2012, 21, 321-330.

139. Beaudin, A.E.; Abarinov, E.V.; Malysheva, O.; Perry, C.A.; Caudill, M.; Stover, P.J. Dietary folate, but not choline, modifies neural tube defect risk in SHMT1 knockout mice. Am. J. Clin. Nutr. 2012, 95, 109-114.

140. Beaudin, A.E.; Abarinov, E.V.; Noden, D.M.; Perry, C.A.; Chu, S.; Stabler, S.P.; Allen, R.H.; Stover, P.J. SHMT1 and de novo thymidylate biosynthesis underlie folate-responsive neural tube defects in mice. Am. J. Clin. Nutr. 2011, 93, 789-798.

141. Christensen, K.E.; Deng, L.; Leung, K.Y.; Arning, E.; Bottiglieri, T.; Malysheva, O.V.; Caudill, M.A.; Krupenko, N.I.; Greene, N.D.; Jerome-Majewska, L.; et al. A novel mouse model for genetic variation in 10-formyltetrahydrofolate synthetase exhibits disturbed purine synthesis with impacts on pregnancy and embryonic development. Hum. Mol. Genet. 2013, 22, 3705-3719.

142. Barbera, J.P.; Rodriguez, T.A.; Greene, N.D.; Weninger, W.J.; Simeone, A.; Copp, A.J.; Beddington, R.S.; Dunwoodie, S. Folic acid prevents exencephaly in Cited2 deficient mice. Hum. Mol. Genet. 2002, 11, 283-293.

143. Dunlevy, L.P.; Burren, K.A.; Chitty, L.S.; Copp, A.J.; Greene, N.D. Excess methionine suppresses the methylation cycle and inhibits neural tube closure in mouse embryos. FEBS Lett. 2006, 580, 2803-2807.

144. Dunlevy, L.P.; Burren, K.A.; Mills, K.; Chitty, L.S.; Copp, A.J.; Greene, N.D. Integrity of the methylation cycle is essential for mammalian neural tube closure. Birth Defects Res. 2006, 76, 544-552.

145. Afman, L.A.; Blom, H.J.; Drittij, M.J.; Brouns, M.R.; van Straaten, H.W. Inhibition of transmethylation disturbs neurulation in chick embryos. Brain Res. Dev. Brain Res. 2005, 158, 59-65.

146. Essien, F.B.; Wannberg, S.L. Methionine but not folinic acid or vitamin B-12 alters the frequency of neural tube defects in axd mutant mice. J. Nutr. 1993, 123, 27-34.

147. Narisawa, A.; Komatsuzaki, S.; Kikuchi, A.; Niihori, T.; Aoki, Y.; Fujiwara, K.; Tanemura, M.; Hata, A.; Suzuki, Y.; Relton, C.L.; et al. Mutations in genes encoding the glycine cleavage system predispose to neural tube defects in mice and humans. Hum. Mol. Genet. 2012, 21, 1496-1503.

148. Greene, N.D.; Stanier, P.; Moore, G.E. The emerging role of epigenetic mechanisms in the etiology of neural tube defects. Epigenetics 2011, 6, 875-883.

149. Chang, H.; Zhang, T.; Zhang, Z.; Bao, R.; Fu, C.; Wang, Z.; Bao, Y.; Li, Y.; Wu, L.; Zheng, X.; et al. Tissue-specific distribution of aberrant DNA methylation associated with maternal low-folate status in human neural tube defects. J. Nutr. Biochem. 2011, 22, 1172-1177. 
150. Okano, M.; Bell, D.W.; Haber, D.A.; Li, E. DNA methyltransferases DNMT3a and DNMT3b are essential for de novo methylation and mammalian development. Cell 1999, 99, 247-257.

151. Van der Linden, I.J.; Heil, S.G.; van Egmont Petersen, M.; van Straaten, H.W.; den Heijer, M.; Blom, H.J. Inhibition of methylation and changes in gene expression in relation to neural tube defects. Birth Defects Res. 2008, 82, 676-683.

152. Chen, Z.; Karaplis, A.C.; Ackerman, S.L.; Pogribny, I.P.; Melnyk, S.; Lussier-Cacan, S.; Chen, M.F.; Pai, A.; John, S.W.; Smith, R.S.; et al. Mice deficient in methylenetetrahydrofolate reductase exhibit hyperhomocysteinemia and decreased methylation capacity, with neuropathology and aortic lipid deposition. Hum. Mol. Genet. 2001, 10, 433-443.

153. Bjorklund, N.K.; Gordon, R. A hypothesis linking low folate intake to neural tube defects due to failure of post-translation methylations of the cytoskeleton. Int. J. Dev. Biol. 2006, 50, 135-141.

154. Moephuli, S.R.; Klein, N.W.; Baldwin, M.T.; Krider, H.M. Effects of methionine on the cytoplasmic distribution of actin and tubulin during neural tube closure in rat embryos. Proc. Natl. Acad. Sci. USA 1997, 94, 543-548.

155. Felkner, M.; Suarez, L.; Canfield, M.A.; Brender, J.D.; Sun, Q. Maternal serum homocysteine and risk for neural tube defects in a Texas-Mexico border population. Birth Defects Res. 2009, 85, 574-581.

156. Gaber, K.R.; Farag, M.K.; Soliman, S.E.; El-Bassyouni, H.T.; El-Kamah, G. Maternal vitamin B12 and the risk of fetal neural tube defects in Egyptian patients. Clin. Lab. 2007, 53, 69-75.

157. Gu, Q.; Li, Y.; Cui, Z.L.; Luo, X.P. Homocysteine, folate, vitamin B12 and B6 in mothers of children with neural tube defects in Xinjiang, China. Acta Paediatr. 2012, 101, e486-e490.

158. Mills, J.L.; McPartlin, J.M.; Kirke, P.N.; Lee, Y.J.; Conley, M.R.; Weir, D.G.; Scott, J.M. Homocysteine metabolism in pregnancies complicated by neural-tube defects. Lancet 1995, 345, $149-151$.

159. Van der Put, N.M.; Thomas, C.M.; Eskes, T.K.; Trijbels, F.J.; Steegers-Theunissen, R.P.; Mariman, E.C.; de Graaf-Hess, A.; Smeitink, J.A.; Blom, H.J. Altered folate and vitamin B12 metabolism in families with spina bifida offspring. QJM 1997, 90, 505-510.

160. Wenstrom, K.D.; Johanning, G.L.; Owen, J.; Johnston, K.E.; Acton, S.; Cliver, S.; Tamura, T. Amniotic fluid homocysteine levels, 5,10-methylenetetrahydrafolate reductase genotypes, and neural tube closure sites. Am. J. Med. Genet. 2000, 90, 6-11.

161. Ceyhan, S.T.; Beyan, C.; Atay, V.; Yaman, H.; Alanbay, I.; Kaptan, K.; Baser, I. Serum vitamin B12 and homocysteine levels in pregnant women with neural tube defect. Gynecol. Endocrinol. 2010, 26, 578-581.

162. Felix, T.M.; Leistner, S.; Giugliani, R. Metabolic effects and the methylenetetrahydrofolate reductase (MTHFR) polymorphism associated with neural tube defects in southern Brazil. Birth Defects Res. 2004, 70, 459-463.

163. Grandone, E.; Corrao, A.M.; Colaizzo, D.; Vecchione, G.; di Girgenti, C.; Paladini, D.; Sardella, L.; Pellegrino, M.; Zelante, L.; Martinelli, P.; et al. Homocysteine metabolism in families from southern Italy with neural tube defects: Role of genetic and nutritional determinants. Prenat. Diagn. 2006, 26, 1-5. 
164. Groenen, P.M.; van Rooij, I.A.; Peer, P.G.; Gooskens, R.H.; Zielhuis, G.A.; Steegers-Theunissen, R.P. Marginal maternal vitamin B12 status increases the risk of offspring with spina bifida. Am. J. Obstet. Gynecol. 2004, 191, 11-17.

165. Ratan, S.K.; Rattan, K.N.; Pandey, R.M.; Singhal, S.; Kharab, S.; Bala, M.; Singh, V.; Jhanwar, A. Evaluation of the levels of folate, vitamin B12, homocysteine and fluoride in the parents and the affected neonates with neural tube defect and their matched controls. Pediatr. Surg. Int. 2008, 24, 803-808.

166. Zhang, H.Y.; Luo, G.A.; Liang, Q.L.; Wang, Y.; Yang, H.H.; Wang, Y.M.; Zheng, X.Y.; Song, X.M.; Chen, G.; Zhang, T.; et al. Neural tube defects and disturbed maternal folate- and homocysteine-mediated one-carbon metabolism. Exp. Neurol. 2008, 212, 515-521.

167. Graham, A.; Brender, J.D.; Sharkey, J.R.; Zhu, L.; Felkner, M.; Suarez, L.; Canfield, M.A. Dietary methionine intake and neural tube defects in Mexican-American women. Birth Defects Res. 2010, 88, 451-457.

168. Shaw, G.M.; Velie, E.M.; Schaffer, D.M. Is dietary intake of methionine associated with a reduction in risk for neural tube defect-affected pregnancies? Teratology 1997, 56, 295-299.

169. Shoob, H.D.; Sargent, R.G.; Thompson, S.J.; Best, R.G.; Drane, J.W.; Tocharoen, A. Dietary methionine is involved in the etiology of neural tube defect-affected pregnancies in humans. J. Nutr. 2001, 131, 2653-2658.

170. Rosenquist, T.H.; Finnell, R.H. Genes, folate and homocysteine in embryonic development. Proc. Nutr. Soc. 2001, 60, 53-61.

171. Van Mil, N.H.; Oosterbaan, A.M.; Steegers-Theunissen, R.P. Teratogenicity and underlying mechanisms of homocysteine in animal models: A review. Reprod. Toxicol. 2010, 30, 520-531.

172. Afman, L.A.; Blom, H.J.; van der Put, N.M.; van Straaten, H.W. Homocysteine interference in neurulation: A chick embryo model. Birth Defects Res. 2003, 67, 421-428.

173. Rosenquist, T.H.; Ratashak, S.A.; Selhub, J. Homocysteine induces congenital defects of the heart and neural tube: Effect of folic acid. Proc. Natl. Acad. Sci. USA 1996, 93, 15227-15232.

174. Vanaerts, L.A.; Blom, H.J.; Deabreu, R.A.; Trijbels, F.J.; Eskes, T.K.; Copius Peereboom-Stegeman, J.H.; Noordhoek, J. Prevention of neural tube defects by and toxicity of L-homocysteine in cultured postimplantation rat embryos. Teratology 1994, 50, 348-360.

175. Bennett, G.D.; Vanwaes, J.; Moser, K.; Chaudoin, T.; Starr, L.; Rosenquist, T.H. Failure of homocysteine to induce neural tube defects in a mouse model. Birth Defects Res. B 2006, 77, 89-94.

176. Greene, N.D.; Dunlevy, L.E.; Copp, A.J. Homocysteine is embryotoxic but does not cause neural tube defects in mouse embryos. Anat. Embryol. 2003, 206, 185-191.

177. Watanabe, M.; Osada, J.; Aratani, Y.; Kluckman, K.; Reddick, R.; Malinow, M.R.; Maeda, N. Mice deficient in cystathionine beta-synthase: Animal models for mild and severe homocyst(e)inemia. Proc. Natl. Acad. Sci. USA 1995, 92, 1585-1589.

178. Carmichael, S.L.; Yang, W.; Shaw, G.M. Periconceptional nutrient intakes and risks of neural tube defects in California. Birth Defects Res. 2010, 88, 670-678.

179. Magnus, P.; Magnus, E.M.; Berg, K. Increased levels of apo-transcobalamins I and II in amniotic fluid from pregnant women with previous neural tube defect offspring. Clin. Genet. 1986, 30, 167-172. 
180. Li, F.; Watkins, D.; Rosenblatt, D.S. Vitamin B(12) and birth defects. Mol. Genet. Metab. 2009, 98, 166-172.

181. Cech, I.; Burau, K.D. Serological differences in folate/vitamin B12 in pregnancies affected by neural tube defects. South. Med. J. 2010, 103, 419-424.

182. Kirke, P.N.; Molloy, A.M.; Daly, L.E.; Burke, H.; Weir, D.G.; Scott, J.M. Maternal plasma folate and vitamin B12 are independent risk factors for neural tube defects. Q. J. Med. 1993, 86, 703-708.

183. Molloy, A.M.; Kirke, P.N.; Troendle, J.F.; Burke, H.; Sutton, M.; Brody, L.C.; Scott, J.M.; Mills, J.L. Maternal vitamin B12 status and risk of neural tube defects in a population with high neural tube defect prevalence and no folic acid fortification. Pediatrics 2009, 123, 917-923.

184. Song, Y.Z.; Li, B.X.; Hao, H.; Xin, R.L.; Zhang, T.; Zhang, C.H.; Kobayashi, K.; Wang, Z.N.; Zheng, X.Y. Selective screening for inborn errors of metabolism and secondary methylmalonic aciduria in pregnancy at high risk district of neural tube defects: A human metabolome study by GC-MS in China. Clin. Biochem. 2008, 41, 616-620.

185. Suarez, L.; Hendricks, K.; Felkner, M.; Gunter, E. Maternal serum B12 levels and risk for neural tube defects in a Texas-Mexico border population. Ann. Epidemiol. 2003, 13, 81-88.

186. Zhang, T.; Xin, R.; Gu, X.; Wang, F.; Pei, L.; Lin, L.; Chen, G.; Wu, J.; Zheng, X. Maternal serum vitamin B12, folate and homocysteine and the risk of neural tube defects in the offspring in a high-risk area of China. Public Health Nutr. 2009, 12, 680-686.

187. Afman, L.A.; van der Put, N.M.; Thomas, C.M.; Trijbels, J.M.; Blom, H.J. Reduced vitamin B12 binding by transcobalamin II increases the risk of neural tube defects. QJM 2001, 94, 159-166.

188. Luo, X.; Zhang, L.; Wei, H.; Liu, W.; Wang, M.; Ning, Q. Methylmalonic acid in amniotic fluid and maternal urine as a marker for neural tube defects. J. Huazhong Univ. Sci. Technol. Med. Sci. 2004, 24, 166-169.

189. Mills, J.L.; Tuomilehto, J.; Yu, K.F.; Colman, N.; Blaner, W.S.; Koskela, P.; Rundle, W.E.; Forman, M.; Toivanen, L.; Rhoads, G.G. Maternal vitamin levels during pregnancies producing infants with neural tube defects. J. Pediatr. 1992, 120, 863-871.

190. Mobasheri, E.; Keshtkar, A.; Golalipour, M.J. Maternal folate and vitamin B(12) status and neural tube defects in northern iran: A case control study. Iran. J. Pediatr. 2010, 20, 167-173.

191. Ubbink, J.B.; Christianson, A.; Bester, M.J.; van Allen, M.I.; Venter, P.A.; Delport, R.; Blom, H.J.; van der Merwe, A.; Potgieter, H.; Vermaak, W.J. Folate status, homocysteine metabolism, and methylene tetrahydrofolate reductase genotype in rural South African blacks with a history of pregnancy complicated by neural tube defects. Metabolism 1999, 48, 269-274.

192. Ray, J.G.; Blom, H.J. Vitamin B12 insufficiency and the risk of fetal neural tube defects. QJM 2003, 96, 289-295.

193. Wang, Z.P.; Shang, X.X.; Zhao, Z.T. Low maternal vitamin B(12) is a risk factor for neural tube defects: A meta-analysis. J. Matern. Fetal Neonatal Med. 2012, 25, 389-394.

194. Magnus, P.; Magnus, E.M.; Berg, K. Transcobalamins in the etiology of neural tube defects. Clin. Genet. 1991, 39, 309-310.

195. Ray, J.G.; Wyatt, P.R.; Thompson, M.D.; Vermeulen, M.J.; Meier, C.; Wong, P.Y.; Farrell, S.A.; Cole, D.E. Vitamin B12 and the risk of neural tube defects in a folic-acid-fortified population. Epidemiology 2007, 18, 362-366. 
196. Adams, M.J., Jr.; Khoury, M.J.; Scanlon, K.S.; Stevenson, R.E.; Knight, G.J.; Haddow, J.E.; Sylvester, G.C.; Cheek, J.E.; Henry, J.P.; Stabler, S.P.; et al. Elevated midtrimester serum methylmalonic acid levels as a risk factor for neural tube defects. Teratology 1995, 51, 311-317.

197. Shaw, G.M.; Carmichael, S.L.; Yang, W.; Selvin, S.; Schaffer, D.M. Periconceptional dietary intake of choline and betaine and neural tube defects in offspring. Am. J. Epidemiol. 2004, 160, 102-109.

198. Chandler, A.L.; Hobbs, C.A.; Mosley, B.S.; Berry, R.J.; Canfield, M.A.; Qi, Y.P.; Siega-Riz, A.M.; Shaw, G.M. Neural tube defects and maternal intake of micronutrients related to one-carbon metabolism or antioxidant activity. Birth Defects Res. 2012, 94, 864-874.

199. Enaw, J.O.; Zhu, H.; Yang, W.; Lu, W.; Shaw, G.M.; Lammer, E.J.; Finnell, R.H. Chka and Pcyt1a gene polymorphisms, choline intake and spina bifida risk in a California population. BMC Med. 2006, 4, 36-41.

200. Shaw, G.M.; Finnell, R.H.; Blom, H.J.; Carmichael, S.L.; Vollset, S.E.; Yang, W.; Ueland, P.M. Choline and risk of neural tube defects in a folate-fortified population. Epidemiology 2009, 20, 714-719.

201. Fisher, M.C.; Zeisel, S.H.; Mar, M.H.; Sadler, T.W. Inhibitors of choline uptake and metabolism cause developmental abnormalities in neurulating mouse embryos. Teratology 2001, 64, $114-122$.

202. Kang, S.S.; Zhou, J.; Wong, P.W.; Kowalisyn, J.; Strokosch, G. Intermediate homocysteinemia: A thermolabile variant of methylenetetrahydrofolate reductase. Am. J. Hum. Genet. 1988, 43, 414-421.

203. Van der Put, N.M.; Steegers-Theunissen, R.P.; Frosst, P.; Trijbels, F.J.; Eskes, T.K.; van den Heuvel, L.P.; Mariman, E.C.; den Heyer, M.; Rozen, R.; Blom, H.J. Mutated methylenetetrahydrofolate reductase as a risk factor for spina bifida. Lancet 1995, 346, 1070-1071.

204. Amorim, M.R.; Lima, M.A.; Castilla, E.E.; Orioli, I.M. Non-Latin European descent could be a requirement for association of NTDs and MTHFR variant $677 \mathrm{C}>\mathrm{T}$ : A meta-analysis. Am. J. Med. Genet. A 2007, 143A, 1726-1732.

205. Botto, L.D.; Yang, Q. 5,10-methylenetetrahydrofolate reductase gene variants and congenital anomalies: A huge review. Am. J. Epidemiol. 2000, 151, 862-877.

206. Van der Put, N.M.; Eskes, T.K.; Blom, H.J. Is the common 677C > T mutation in the methylenetetrahydrofolate reductase gene a risk factor for neural tube defects? A meta-analysis. QJM 1997, 90, 111-115.

207. Yan, L.; Zhao, L.; Long, Y.; Zou, P.; Ji, G.; Gu, A.; Zhao, P. Association of the maternal mthfr C677T polymorphism with susceptibility to neural tube defects in offsprings: Evidence from 25 case-control studies. PLoS One 2012, 7, e41689, doi:10.1371/journal.pone.0041689.

208. Boyles, A.L.; Billups, A.V.; Deak, K.L.; Siegel, D.G.; Mehltretter, L.; Slifer, S.H.; Bassuk, A.G.; Kessler, J.A.; Reed, M.C.; Nijhout, H.F.; et al. Neural tube defects and folate pathway genes: Family-based association tests of gene-gene and gene-environment interactions. Environ. Health Perspect. 2006, 114, 1547-1552. 
209. De Marco, P.; Calevo, M.G.; Moroni, A.; Merello, E.; Raso, A.; Finnell, R.H.; Zhu, H.; Andreussi, L.; Cama, A.; Capra, V. Reduced folate carrier polymorphism (80A > G) and neural tube defects. Eur. J. Hum. Genet. 2003, 11, 245-252.

210. Speer, M.C.; Nye, J.; McLone, D.; Worley, G.; Melvin, E.C.; Viles, K.D.; Franklin, A.; Drake, C.; Mackey, J.; George, T.M. Possible interaction of genotypes at cystathionine beta-synthase and methylenetetrahydrofolate reductase (MTHFR) in neural tube defects. NTD collaborative group. Clin. Genet. 1999, 56, 142-144.

211. Wilson, A.; Platt, R.; Wu, Q.; Leclerc, D.; Christensen, B.; Yang, H.; Gravel, R.A.; Rozen, R. A common variant in methionine synthase reductase combined with low cobalamin (vitamin B12) increases risk for spina bifida. Mol. Genet. Metab. 1999, 67, 317-323.

212. Van der Linden, I.J.; den Heijer, M.; Afman, L.A.; Gellekink, H.; Vermeulen, S.H.; Kluijtmans, L.A.; Blom, H.J. The methionine synthase reductase $66 \mathrm{~A}>\mathrm{G}$ polymorphism is a maternal risk factor for spina bifida. J. Mol. Med. 2006, 84, 1047-1054.

213. Shaw, G.M.; Lammer, E.J.; Zhu, H.; Baker, M.W.; Neri, E.; Finnell, R.H. Maternal periconceptional vitamin use, genetic variation of infant reduced folate carrier (A80G), and risk of spina bifida. Am. J. Med. Genet. 2002, 108, 1-6.

214. Shaw, G.M.; Rozen, R.; Finnell, R.H.; Wasserman, C.R.; Lammer, E.J. Maternal vitamin use, genetic variation of infant methylenetetrahydrofolate reductase, and risk for spina bifida. Am. J. Epidemiol. 1998, 148, 30-37.

215. Shang, Y.; Zhao, H.; Niu, B.; Li, W.I.; Zhou, R.; Zhang, T.; Xie, J. Correlation of polymorphism of MTHFRS and RFC-1 genes with neural tube defects in China. Birth Defects Res. 2008, 82, 3-7.

216. Volcik, K.A.; Blanton, S.H.; Tyerman, G.H.; Jong, S.T.; Rott, E.J.; Page, T.Z.; Romaine, N.K.; Northrup, H. Methylenetetrahydrofolate reductase and spina bifida: Evaluation of level of defect and maternal genotypic risk in Hispanics. Am. J. Med. Genet. 2000, 95, 21-27.

217. Franke, B.; Vermeulen, S.H.; Steegers-Theunissen, R.P.; Coenen, M.J.; Schijvenaars, M.M.; Scheffer, H.; den Heijer, M.; Blom, H.J. An association study of 45 folate-related genes in spina bifida: Involvement of cubilin (CUBN) and trna aspartic acid methyltransferase 1 (TRDMT1). Birth Defects Res. 2009, 85, 216-226.

218. Afman, L.A.; Lievers, K.J.; van der Put, N.M.; Trijbels, F.J.; Blom, H.J. Single nucleotide polymorphisms in the transcobalamin gene: Relationship with transcobalamin concentrations and risk for neural tube defects. Eur. J. Hum. Genet. 2002, 10, 433-438.

219. Gueant-Rodriguez, R.M.; Rendeli, C.; Namour, B.; Venuti, L.; Romano, A.; Anello, G.; Bosco, P.; Debard, R.; Gerard, P.; Viola, M.; et al. Transcobalamin and methionine synthase reductase mutated polymorphisms aggravate the risk of neural tube defects in humans. Neurosci. Lett. 2003, 344, 189-192.

220. Swanson, D.A.; Pangilinan, F.; Mills, J.L.; Kirke, P.N.; Conley, M.; Weiler, A.; Frey, T.; Parle-McDermott, A.; O’Leary, V.B.; Seltzer, R.R.; et al. Evaluation of transcobalamin II polymorphisms as neural tube defect risk factors in an Irish population. Birth Defects Res. 2005, 73, 239-244.

221. Pietrzyk, J.J.; Bik-Multanowski, M. 776C > G polymorphism of the transcobalamin II Gene as a risk factor for spina bifida. Mol. Genet. Metab. 2003, 80, 364, doi:10.1016/S1096-7192(03) 00131-8. 
222. Morin, I.; Platt, R.; Weisberg, I.; Sabbaghian, N.; Wu, Q.; Garrow, T.A.; Rozen, R. Common variant in betaine-homocysteine methyltransferase (BHMT) and risk for spina bifida. Am. J. Med. Genet. 2003, 119A, 172-176.

223. Zhu, H.; Curry, S.; Wen, S.; Wicker, N.J.; Shaw, G.M.; Lammer, E.J.; Yang, W.; Jafarov, T.; Finnell, R.H. Are the betaine-homocysteine methyltransferase (BHMT and BHMT2) genes risk factors for spina bifida and orofacial clefts? Am. J. Med. Genet. A 2005, 135, 274-277.

224. Johnson, W.G.; Stenroos, E.S.; Spychala, J.R.; Chatkupt, S.; Ming, S.X.; Buyske, S. New 19 bp deletion polymorphism in intron-1 of dihydrofolate reductase (DHFR): A risk factor for spina bifida acting in mothers during pregnancy? Am. J. Med. Genet. A 2004, 124A, 339-345.

225. Doudney, K.; Grinham, J.; Whittaker, J.; Lynch, S.A.; Thompson, D.; Moore, G.E.; Copp, A.J.; Greene, N.D.; Stanier, P. Evaluation of folate metabolism gene polymorphisms as risk factors for open and closed neural tube defects. Am. J. Med. Genet. A 2009, 149A, 1585-1589.

226. Van der Linden, I.J.; Nguyen, U.; Heil, S.G.; Franke, B.; Vloet, S.; Gellekink, H.; den Heijer, M.; Blom, H.J. Variation and expression of dihydrofolate reductase (DHFR) in relation to spina bifida. Mol. Genet. Metab. 2007, 91, 98-103.

227. O’Leary, V.B.; Mills, J.L.; Kirke, P.N.; Parle-McDermott, A.; Swanson, D.A.; Weiler, A.; Pangilinan, F.; Conley, M.; Molloy, A.M.; Lynch, M.; et al. Analysis of the human folate receptor beta gene for an association with neural tube defects. Mol. Genet. Metab. 2003, 79, 129-133.

228. Relton, C.L.; Wilding, C.S.; Pearce, M.S.; Laffling, A.J.; Jonas, P.A.; Lynch, S.A.; Tawn, E.J.; Burn, J. Gene-gene interaction in folate-related genes and risk of neural tube defects in a UK population. J. Med. Genet. 2004, 41, 256-260.

229. Morin, I.; Devlin, A.M.; Leclerc, D.; Sabbaghian, N.; Halsted, C.H.; Finnell, R.; Rozen, R. Evaluation of genetic variants in the reduced folate carrier and in glutamate carboxypeptidase II for spina bifida risk. Mol. Genet. Metab. 2003, 79, 197-200.

230. Brody, L.C.; Conley, M.; Cox, C.; Kirke, P.N.; McKeever, M.P.; Mills, J.L.; Molloy, A.M.; O’Leary, V.B.; Parle-McDermott, A.; Scott, J.M.; et al. A polymorphism, r653q, in the trifunctional enzyme methylenetetrahydrofolate dehydrogenase/methenyltetrahydrofolate cyclohydrolase/formyltetrahydrofolate synthetase is a maternal genetic risk factor for neural tube defects: Report of the birth defects research group. Am. J. Hum. Genet. 2002, 71, 1207-1215.

231. De Marco, P.; Merello, E.; Calevo, M.G.; Mascelli, S.; Raso, A.; Cama, A.; Capra, V. Evaluation of a methylenetetrahydrofolate-dehydrogenase $1958 \mathrm{G}>$ A polymorphism for neural tube defect risk. J. Hum. Genet. 2006, 51, 98-103.

232. Hol, F.A.; van der Put, N.M.; Geurds, M.P.; Heil, S.G.; Trijbels, F.J.; Hamel, B.C.; Mariman, E.C.; Blom, H.J. Molecular genetic analysis of the gene encoding the trifunctional enzyme mthfd (methylenetetrahydrofolate-dehydrogenase, methenyltetrahydrofolate-cyclohydrolase, formyltetrahydrofolate synthetase) in patients with neural tube defects. Clin. Genet. 1998, 53, $119-125$.

233. Parle-McDermott, A.; Kirke, P.N.; Mills, J.L.; Molloy, A.M.; Cox, C.; O’Leary, V.B.; Pangilinan, F.; Conley, M.; Cleary, L.; Brody, L.C.; et al. Confirmation of the R653Q polymorphism of the trifunctional C1-synthase enzyme as a maternal risk for neural tube defects in the Irish population. Eur. J. Hum. Genet. 2006, 14, 768-772. 
234. Van der Linden, I.J.; Heil, S.G.; Kouwenberg, I.C.; den Heijer, M.; Blom, H.J. The methylenetetrahydrofolate dehydrogenase (MTHFD1) 1958G > A variant is not associated with spina bifida risk in the Dutch population. Clin. Genet. 2007, 72, 599-600.

235. Parle-McDermott, A.; Pangilinan, F.; O’Brien, K.K.; Mills, J.L.; Magee, A.M.; Troendle, J.; Sutton, M.; Scott, J.M.; Kirke, P.N.; Molloy, A.M.; et al. A common variant in MTHFD1L is associated with neural tube defects and MRNA splicing efficiency. Hum. Mutat. 2009, 30, 1650-1656.

236. Morrison, K.; Papapetrou, C.; Hol, F.A.; Mariman, E.C.; Lynch, S.A.; Burn, J.; Edwards, Y.H. Susceptibility to spina bifida; An association study of five candidate genes. Ann. Hum. Genet. 1998, 62, 379-396.

237. Boduroglu, K.; Alanay, Y.; Alikasifoglu, M.; Aktas, D.; Tuncbilek, E. Analysis of MTHFR 1298A $>\mathrm{C}$ in addition to MTHFR 677C $>\mathrm{T}$ polymorphism as a risk factor for neural tube defects in the Turkish population. Turk. J. Pediatr. 2005, 47, 327-333.

238. De Marco, P.; Calevo, M.G.; Moroni, A.; Arata, L.; Merello, E.; Cama, A.; Finnell, R.H.; Andreussi, L.; Capra, V. Polymorphisms in genes involved in folate metabolism as risk factors for ntds. Eur. J. Pediatr. Surg. 2001, 11, S14-S17.

239. De Marco, P.; Calevo, M.G.; Moroni, A.; Arata, L.; Merello, E.; Finnell, R.H.; Zhu, H.; Andreussi, L.; Cama, A.; Capra, V. Study of MTHFR and ms polymorphisms as risk factors for ntd in the Italian population. J. Hum. Genet. 2002, 47, 319-324.

240. Gonzalez-Herrera, L.; Castillo-Zapata, I.; Garcia-Escalante, G.; Pinto-Escalante, D. A1298c polymorphism of the MTHFR gene and neural tube defects in the state of Yucatan, Mexico. Birth Defects Res. 2007, 79, 622-626.

241. Parle-McDermott, A.; Mills, J.L.; Kirke, P.N.; O’Leary, V.B.; Swanson, D.A.; Pangilinan, F.; Conley, M.; Molloy, A.M.; Cox, C.; Scott, J.M.; et al. Analysis of the MTHFR 1298A > C and 677C $>\mathrm{T}$ polymorphisms as risk factors for neural tube defects. J. Hum. Genet. 2003, 48, 190-193.

242. Van der Put, N.M.; Gabreels, F.; Stevens, E.M.; Smeitink, J.A.; Trijbels, F.J.; Eskes, T.K.; van den Heuvel, L.P.; Blom, H.J. A second common mutation in the methylenetetrahydrofolate reductase gene: An additional risk factor for neural-tube defects? Am. J. Hum. Genet. 1998, 62, 1044-1051.

243. Behunova, J.; Klimcakova, L.; Zavadilikova, E.; Potocekova, D.; Sykora, P.; Podracka, L. Methylenetetrahydrofolate reductase gene polymorphisms and neural tube defects epidemiology in the Slovak population. Birth Defects Res. 2010, 88, 695-700.

244. Gutierrez Revilla, J.I.; Perez Hernandez, F.; Calvo Martin, M.T.; Tamparillas Salvador, M.; Gracia Romero, J. C677T and A1298C MTHFR polymorphisms in the etiology of neural tube defects in Spanish population. Med. Clin. 2003, 120, 441-445.

245. Papapetrou, C.; Lynch, S.A.; Burn, J.; Edwards, Y.H. Methylenetetrahydrofolate reductase and neural tube defects. Lancet 1996, 348, 58, doi:10.1016/S0140-6736(96)90526-7.

246. Rampersaud, E.; Melvin, E.C.; Siegel, D.; Mehltretter, L.; Dickerson, M.E.; George, T.M.; Enterline, D.; Nye, J.S.; Speer, M.C. Updated investigations of the role of methylenetetrahydrofolate reductase in human neural tube defects. Clin. Genet. 2003, 63, 210-214. 
247. Gonzalez-Herrera, L.; Garcia-Escalante, G.; Castillo-Zapata, I.; Canto-Herrera, J.; Ceballos-Quintal, J.; Pinto-Escalante, D.; Diaz-Rubio, F.; del Angel, R.M.; Orozco-Orozco, L. Frequency of the thermolabile variant C677T in the MTHFR gene and lack of association with neural tube defects in the state of Yucatan, Mexico. Clin. Genet. 2002, 62, 394-398.

248. Koch, M.C.; Stegmann, K.; Ziegler, A.; Schroter, B.; Ermert, A. Evaluation of the MTHFR C677T allele and the MTHFR gene locus in a German spina bifida population. Eur. J. Pediatr. 1998, 157, 487-492.

249. Mornet, E.; Muller, F.; Lenvoise-Furet, A.; Delezoide, A.L.; Col, J.Y.; Simon-Bouy, B.; Serre, J.L. Screening of the C677T mutation on the methylenetetrahydrofolate reductase gene in french patients with neural tube defects. Hum. Genet. 1997, 100, 512-514.

250. De Franchis, R.; Buoninconti, A.; Mandato, C.; Pepe, A.; Sperandeo, M.P.; del Gado, R.; Capra, V.; Salvaggio, E.; Andria, G.; Mastroiacovo, P. The C677T mutation of the 5,10-methylenetetrahydrofolate reductase gene is a moderate risk factor for spina bifida in Italy. J. Med. Genet. 1998, 35, 1009-1013.

251. Johanning, G.L.; Tamura, T.; Johnston, K.E.; Wenstrom, K.D. Comorbidity of 5,10-methylenetetrahydrofolate reductase and methionine synthase gene polymorphisms and risk for neural tube defects. J. Med. Genet. 2000, 37, 949-951.

252. Kirke, P.N.; Mills, J.L.; Molloy, A.M.; Brody, L.C.; O’Leary, V.B.; Daly, L.; Murray, S.; Conley, M.; Mayne, P.D.; Smith, O.; et al. Impact of the MTHFR C677T polymorphism on risk of neural tube defects: Case-control study. BMJ 2004, 328, 1535-1536.

253. Kirke, P.N.; Mills, J.L.; Whitehead, A.S.; Molloy, A.; Scott, J.M. Methylenetetrahydrofolate reductase mutation and neural tube defects. Lancet 1996, 348, 1037-1038.

254. Ou, C.Y.; Stevenson, R.E.; Brown, V.K.; Schwartz, C.E.; Allen, W.P.; Khoury, M.J.; Rozen, R.; Oakley, G.P., Jr.; Adams, M.J., Jr. 5,10 methylenetetrahydrofolate reductase genetic polymorphism as a risk factor for neural tube defects. Am. J. Med. Genet. 1996, 63, 610-614.

255. Pietrzyk, J.J.; Bik-Multanowski, M.; Sanak, M.; Twardowska, M. Polymorphisms of the 5,10-methylenetetrahydrofolate and the methionine synthase reductase genes as independent risk factors for spina bifida. J. Appl. Genet. 2003, 44, 111-113.

256. Shields, D.C.; Kirke, P.N.; Mills, J.L.; Ramsbottom, D.; Molloy, A.M.; Burke, H.; Weir, D.G.; Scott, J.M.; Whitehead, A.S. The thermolabile variant of methylenetetrahydrofolate reductase and neural tube defects: An evaluation of genetic risk and the relative importance of the genotypes of the embryo and the mother. Am. J. Hum. Genet. 1999, 64, 1045-1055.

257. Whitehead, A.S.; Gallagher, P.; Mills, J.L.; Kirke, P.N.; Burke, H.; Molloy, A.M.; Weir, D.G.; Shields, D.C.; Scott, J.M. A genetic defect in 5,10 methylenetetrahydrofolate reductase in neural tube defects. QJM 1995, 88, 763-766.

258. Davalos, I.P.; Olivares, N.; Castillo, M.T.; Cantu, J.M.; Ibarra, B.; Sandoval, L.; Moran, M.C.; Gallegos, M.P.; Chakraborty, R.; Rivas, F. The C677T polymorphism of the methylenetetrahydrofolate reductase gene in Mexican mestizo neural-tube defect parents, control mestizo and native populations. Ann. Genet. 2000, 43, 89-92. 
259. Lucock, M.; Daskalakis, I.; Briggs, D.; Yates, Z.; Levene, M. Altered folate metabolism and disposition in mothers affected by a spina bifida pregnancy: Influence of $677 \mathrm{C}>\mathrm{T}$ methylenetetrahydrofolate reductase and 2756A $>\mathrm{G}$ methionine synthase genotypes. Mol. Genet. Metab. 2000, 70, 27-44.

260. Martinez de Villarreal, L.E.; Delgado-Enciso, I.; Valdez-Leal, R.; Ortiz-Lopez, R.; Rojas-Martinez, A.; Limon-Benavides, C.; Sanchez-Pena, M.A.; Ancer-Rodriguez, J.; Barrera-Saldana, H.A.; Villarreal-Perez, J.Z. Folate levels and N(5)-N(10)-methylenetetrahydrofolate reductase genotype (MTHFR) in mothers of offspring with neural tube defects: A case-control study. Arch. Med. Res. 2001, 32, 277-282.

261. Richter, B.; Stegmann, K.; Roper, B.; Boddeker, I.; Ngo, E.T.; Koch, M.C. Interaction of folate and homocysteine pathway genotypes evaluated in susceptibility to neural tube defects (NTD) in a German population. J. Hum. Genet. 2001, 46, 105-109.

262. O’Leary, V.; Pangilinan, F.; Cox, C.; Parle-McDermott, A.; Conley, M.; Molloy, A.M.; Kirke, P.N.; Mills, J.L.; Brody, L.C.; Scott, J.M. Reduced folate carrier polymorphisms and neural tube defect risk. Mol. Genet. Metab. 2006, 87, 364-369.

263. Pei, L.; Zhu, H.; Ren, A.; Li, Z.; Hao, L.; Finnell, R.H. Reduced folate carrier gene is a risk factor for neural tube defects in a Chinese population. Birth Defects Res. 2005, 73, 430-433.

264. Vieira, A.R.; Murray, J.C.; Trembath, D.; Orioli, I.M.; Castilla, E.E.; Cooper, M.E.; Marazita, M.L.; Lennon-Graham, F.; Speer, M. Studies of reduced folate carrier 1 (RFC1) A80G and 5,10-methylenetetrahydrofolate reductase (MTHFR) C677T polymorphisms with neural tube and orofacial cleft defects. Am. J. Med. Genet. 2005, 135, 220-223.

265. Wang, H.G.; Wang, J.L.; Zhang, J.; Zhao, L.X.; Zhai, G.X.; Xiang, Y.Z.; Chang, P. Reduced folate carrier A80G polymorphism and susceptibility to neural tube defects: A meta-analysis. Gene 2012, 510, 180-184.

266. Heil, S.G.; van der Put, N.M.; Waas, E.T.; den Heijer, M.; Trijbels, F.J.; Blom, H.J. Is mutated serine hydroxymethyltransferase (SHMT) involved in the etiology of neural tube defects? Mol. Genet. Metab. 2001, 73, 164-172.

267. O’Leary, V.B.; Mills, J.L.; Pangilinan, F.; Kirke, P.N.; Cox, C.; Conley, M.; Weiler, A.; Peng, K.; Shane, B.; Scott, J.M.; et al. Analysis of methionine synthase reductase polymorphisms for neural tube defects risk association. Mol. Genet. Metab. 2005, 85, 220-227.

268. Morrison, K.; Edwards, Y.H.; Lynch, S.A.; Burn, J.; Hol, F.; Mariman, E. Methionine synthase and neural tube defects. J. Med. Genet. 1997, 34, 958-960.

269. Shaw, G.M.; Todoroff, K.; Finnell, R.H.; Lammer, E.J.; Leclerc, D.; Gravel, R.A.; Rozen, R. Infant methionine synthase variants and risk for spina bifida. J. Med. Genet. 1999, 36, 86-87.

270. Van der Put, N.M.; van der Molen, E.F.; Kluijtmans, L.A.; Heil, S.G.; Trijbels, J.M.; Eskes, T.K.; van Oppenraaij-Emmerzaal, D.; Banerjee, R.; Blom, H.J. Sequence analysis of the coding region of human methionine synthase: Relevance to hyperhomocysteinaemia in neural-tube defects and vascular disease. QJM 1997, 90, 511-517.

271. Zhu, H.; Wicker, N.J.; Shaw, G.M.; Lammer, E.J.; Hendricks, K.; Suarez, L.; Canfield, M.; Finnell, R.H. Homocysteine remethylation enzyme polymorphisms and increased risks for neural tube defects. Mol. Genet. Metab. 2003, 78, 216-221. 
272. Doolin, M.T.; Barbaux, S.; McDonnell, M.; Hoess, K.; Whitehead, A.S.; Mitchell, L.E. Maternal genetic effects, exerted by genes involved in homocysteine remethylation, influence the risk of spina bifida. Am. J. Hum. Genet. 2002, 71, 1222-1226.

273. Ouyang, S.; Li, Y.; Liu, Z.; Chang, H.; Wu, J. Association between MTR A2756G and MTRR A66G polymorphisms and maternal risk for neural tube defects: A meta-analysis. Gene 2013, $515,308-312$.

274. Selhub, J.; Paul, L. Folic acid fortification: Why not vitamin B12 also? Biofactors 2011, 37, 269-271.

275. Benevenga, N.J. Consideration of betaine and one-carbon sources of N5-methyltetrahydrofolate for use in homocystinuria and neural tube defects. Am. J. Clin. Nutr. 2007, 85, 946-949.

(C) 2013 by the authors; licensee MDPI, Basel, Switzerland. This article is an open access article distributed under the terms and conditions of the Creative Commons Attribution license (http://creativecommons.org/licenses/by/3.0/). 